\title{
The Impact of a Customs Union with the E U on Turkey's Welfare, Employment and Income Distribution: An AGE Model with Alternative Labour Market Structures
}

\author{
Robert A. De Santis \\ The Kiel Institute of World Economics
}

\begin{abstract}
The economic implications and the income distribution effects of the customs union ( CU) between Turkey and the E uropean Union ( $E U$ ) have been studied by applying a general equilibrium model to the Turkish economy under alter native hypotheses for the labour market. The numerical results show that, regardless of the assumptions postulated for the labour market, manufacturing production and trade, in particular textiles, wearing apparel, leather and fur products, grow despite the protection loss; and the standard VAT rate has to increase to $21-22 \%$ for the trade policy to be revenue neutral. The CU is poten tially Pareto superior. Urban ( rural) groups are better (worse) off in the wage curve scenario, where wages and unemployment are negatively related; while urban (rural) groups are worse (better) off in the scenario with fixed or flexi -
\end{abstract}

* Correspondence Address: Düsternbrooker Weg 120, D-24105 Kiel, (E-mail) r.desantis@ifw.uni-kiel.de I am indebted to Jeffery Round and John Whalley for their valuable suggestions and comments at different stages. M oreover, I have benefited from discussions with Rod Falvey, Gernot Klepper and Carlo Perroni.

Financial support from the UK Economic Social Research Council is gratefully acknowledged. All errors are my responsibility.

C2000 - Center for International Economics, Sejong Institution. All rights reserved. 
ble real wages. Also the impact on income inequality is ambiguous, rising (declining) in the wage curve ( fixed and flexible real wage) scenario. This lat ter result is partly driven by the large impact on income inequality between urban and rural groups. However, despite the relatively large fall in tariffs, the impact on overall income inequality is small. Regarding the impact on employ ment, the model predicts the creation of 68,000 new jobs in the wage curve sce nario, and the loss of almost 100,000 jobs in the scenario with fixed real wages. (JEL Classifications: D58, F14, F15, F17) \& Key Words: Customs Union, Income distribution, Employment, AGE analysis, Turkey.>

\section{Introduction}

In December 1995, the European Parliament ratified the customs union (CU) agreement with Turkey for mining and industrial products, with the exception of the commodities subject to the Common Agricultural Policy (CAP). This preferential trade arrangement came into force in January 1996. Despite this, very few attempts have been made to analyse the economic implications of this agreement on Turkey (Harrison, et al. [1997]; Mercenier and Yeldan, [1997]), and none of them has examined the impact on employment, and the distribution of income.

Turkey is a middle income developing country abundant of both workers with a basic education and workers with virtually no schooling. Since, before the CU, Turkey levied very high sectoral tariffs on manufacturing goods imported from both the EU and the non member states, and since the European CAP is not part of the CU protocol, this preferential trading arrangement with the EU might cause a wage decline of the basic skilled workers relative to both the skilled workers, who are mainly employed in services and are richer, and the non-skilled workers, who are employed in agriculture and are poorer. As a result, the impact on inequality is ambiguous. In addition, the Stolper-Samuelson theorem states that with trade the aggregate welfare gains are accompanied by an income redistribution effect in favour of the factor which is intensively used in the production of the exportable good. The theorem enables one to determine the relationship which may exist between foreign trade and functional income distribution, but it cannot predict the effects on the size distribution of income, which 
depend upon the combined ownership structure of primary factors of production. Nowadays, households receive their income from different sources, including capital, in the form of interest and dividends. In this study, each household income group engages its own members in eight different labour activities, owns two different shares of capital factor of production, and is a recipient of part of the quota rents which originate from the VER agreements with the EU. ${ }^{1}$ It seems that the issue of international trade and the size distribution of income has been neglected by trade theory mainly because it requires a general equilibrium framework where sectoral output, trade flows, prices, factor returns, factor inputs and households' income are all simultaneously determined. So I have built a single country Applied General Equilibrium ( $A G E$ ) model for Turkey, which is able to trace such effects in a multi-sector, multi-labour, multi-household framework, to quantify in a general equilibrium setting the effects of the $\mathrm{CU}$ agreement with the EU upon the welfare of rural and urban households, and the functional and the size distribution of income in T urkey.

The first scenario assumes that all labour categories are mobile and that full employment is guaranteed by the flexibility of real wages. ${ }^{2}$ To examine what might be the impact of the $\mathrm{CU}$ agreement on Turkish employment, I consider two alternative hypotheses, which are based upon the assumptions that some forms of labour market rigidities exist. After the 1994 financial cri-

1. The European Commission and the Istanbul Textiles and Clothing Exporters Association (ITKIB) have agreed quantitative restrictions and price mechanisms for Turkish textiles in [1982] and for clothing categories in [1986]. Since then, the VERs arrangements have been regularly renewed (GATT [1994]). The elimination of the VER on Turkish textiles and apparel exports is an important issue of the preferential trade arrangement agreed with the EU. Textiles and apparel comprises $13 \%$ of Turkey's industrial production, and their exports represent $38 \%$ of merchandise exports. M ost of them are exported to the European market. Hence, the elimination of the VERs could have an important impact on the Turkish economy. Certainly, the quota rents on textiles and apparel accruing to the exporting firms, and transferred to households, would be annulled; although the output of these sectors would expand, affecting sectoral factor mobility, welfare and, as a consequence, the distribution of income.

2. Onaran [1999] argues that the econometric evidence, based upon private manufacturing observations available for the period 1963-94, suggests that Turkish wages are flexible. 
sis, which so strongly hit the Turkish economy as to force the government in April 1994 to launch an ambitious stabilisation programme, the average wages in Turkish manufacturing, deflated by the urban areas consumer price index (CPI), moved around a constant value, and those deflated by the wholesale price index (WPI) fluctuated less markedly (see Fig. 1, which shows the average monthly nominal wage rate in manufacturing deflated by either the monthly general WPI or the monthly urban areas CPI). ${ }^{3}$ Given this statistical evidence, one scenario postulates that real wages are constant, whereas a second scenario is based upon the so-called wage curve hypothesis, according to which economies are characterised by a long-run negative relationship between the wage rate and unemployment, mainly because as unemployment declines trade unions' power strengthens (Blanchflower and Oswald [1994]).

In summary, the economic impact of the regional agreement with the EU is examined under three alternative hypotheses for the Turkish labour market: (i) full employment and flexible real wages; (ii) unemployment and fixed real wages; (iii) unemployment and flexible real wages, which adjust to unemployment levels.

The study also consists of a further four sections. Section II defines the algebraic specification of the model, and the measures of welfare and income inequality. Section III describes the benchmark data set. Section IV explores the effects of the policy simulations, and the final section provides some conclusions.

\section{Model Specification}

The trade model presented in this study is a standard static 20-sector, 1capital, 8-labour, 39-household AGE model for Turkey with perfect competi-

3. Kirmanoglu and Yazgan [1998] have tested the relation between labour productivity, the real wage rate and employment in Turkish manufacturing with monthly data covering the period 1988-1997. They cannot reject the hypothesis of weak exogeneity for the real wage rate. However, when the analysis is carried out with Granger causality tests, the assumption that the real wage rate is independent of labour productivity and employment fails. 


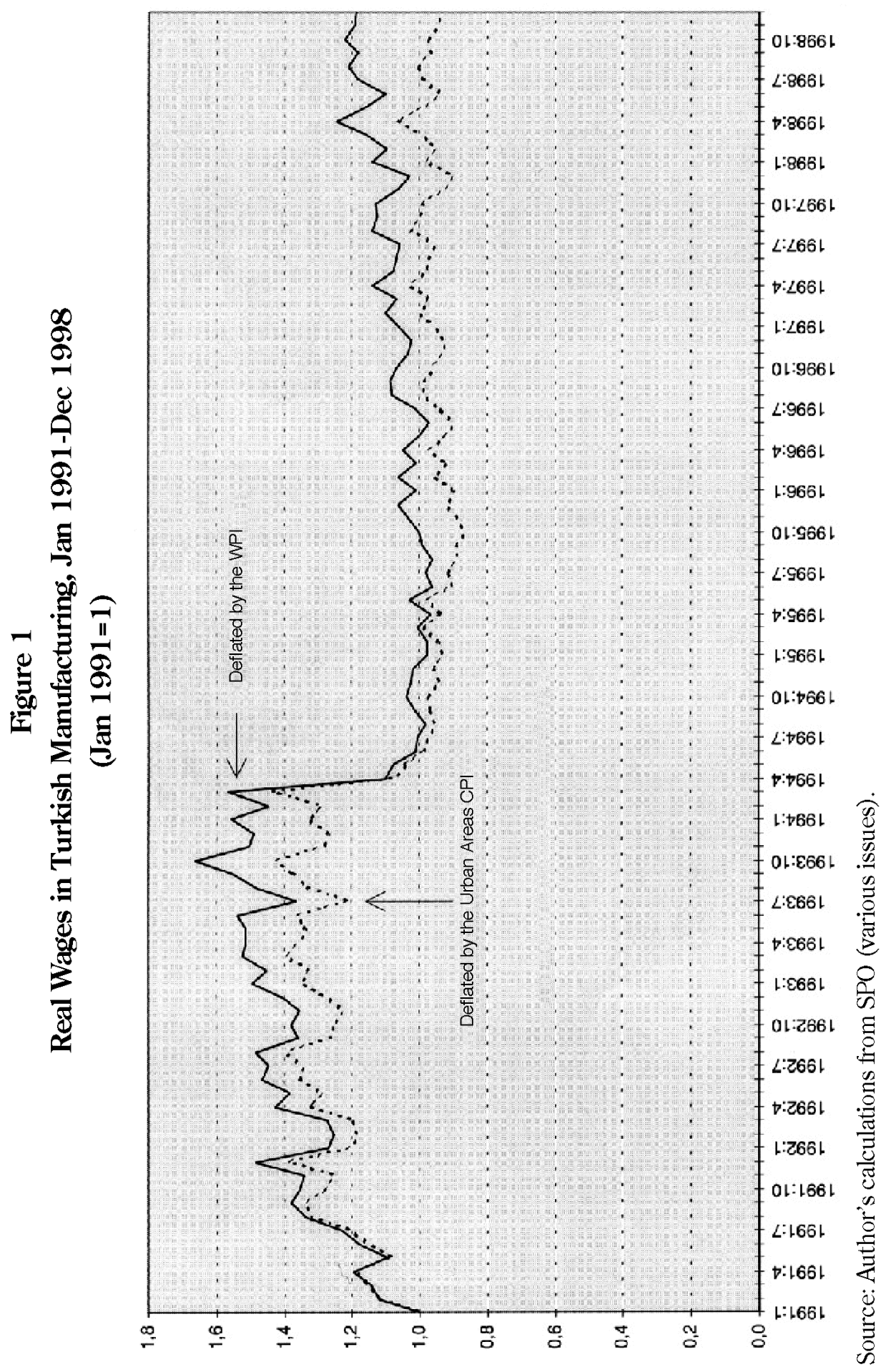


tion and constant returns to scale. It is characterised by intra-industry trade as each tradable commodity is exchanged in five different markets: the domestic market; the markets for imports from the EU, and the RoW; and the markets for export to the EU, and the RoW. This implies that although Turkey is assumed to be a price taker of international goods, domestic prices are endogenously determined. The numeraire of the model is represented by the price of construction, the only nontradable good. To simplify the presentation, the specification of the model is divided into six components: production technology and factor demand, treatment of traded goods and foreign sector closure, household revenues and consumption, government revenues and expenditure, goods market equilibrium, welfare and the income distribution measures.

\section{A. Technology and Factor Demand}

The production technology is described by a four stage nested separable CES function. At the first stage, sectoral production, $Y_{i}$, is generated as a Leontief function between raw-material inputs, $x_{j i}$, which are assumed to be strictly complementar $y$, and the value added, which is, at the second stage, a CES combination of composite skilled labour/ capital and composite unskilled labour, $A L_{i}^{u}$, with elasticity of substitution $\sigma_{i}$. At the third stage, composite skilled labour/ capital is a CES combination of composite skilled labour, $A L_{i}^{s}$, and capital, $A K_{i}$, with elasticity of substitution ${ }_{i}$, which is assumed lower than $\sigma_{i}$. Thus, the production function captures Griliches's hypothesis of "skilled labour-capital complementarity", according to which capital and skilled labour have a lower elasticity of substitution than capital and unskilled labour, so that the skilled labour-capital complementarity holds in relative terms (Griliches [1969]). ${ }^{4}$ Such a production function is:

$$
Y_{i}=\min \left[\frac{1}{a_{j i}} x_{j i}, \frac{1}{a_{i}^{v}}\left\{{ }_{i}^{u}\left[{ }_{i}^{s} A L_{i}^{s^{-u}}+\left(1-{ }_{i}^{s}\right) A K_{i}^{\tilde{u}}\right]^{i^{\prime I^{\prime}}{ }^{i}}+\left(1-{ }_{i}^{u}\right) A L_{i}^{u}\right\}^{1 / i}\right\rceil \text {, }
$$

where $\mathrm{a}_{\mathrm{ji}}$ denotes the Leontief input-output coefficients, $a_{i}^{v}$ the value added

4. Recent evidence in support of this hypothesis for the US manufacturing industries can be found in Bartel and Lichtenberg [1987] and Berndt, et al. [1992]. 
requirement per unit of sectoral output, ${ }_{i}^{s}$ the share parameter of the composite skilled labour/ capital function, ${ }_{i}^{u}$ the share parameter of the value added function, $\tilde{}_{i}=1-1 /{ }^{\sim_{i}}$ and ${ }_{i}=1-1 /{ }_{i}$. The idea that $A L_{i}^{s}$ and $A K_{i}$ are relatively complementary as compared with $A L_{i}^{u}$ is captured by the condition that ${ }_{i}<{ }_{i}$. At the final stage, composite skilled labour and composite unskilled labour are respectively a CES aggregation of different skilled occupational categories and of different unskilled occupational categories. ${ }^{5}$

It is assumed that factor inputs are mobile between sectors and that total capital demand always equates exogenous aggregate capital $\left(\overline{A K}=\sum_{i} A K_{i}\right)$. Producers behave competitively and the factor returns equal their marginal revenue product. In addition, since Turkish farmers are virtually without schooling, they are unemployable in manufacturing. Or to put it in another way, since $95 \%$ of employed persons in Turkish agriculture are selfemployed or unpaid family labour (Bulutay [1995]), it is assumed that trade policy affects only farmers' wages. ${ }^{6}$

\section{(a) Labour Market Equilibrium and the Full Employment $H$ ypothesis}

Under the hypothesis of full employment and wage flexibility, total labour demand of each category is equal to exogenous labour supply of each category, $\bar{L}_{c}^{s}$. Then,

$$
\bar{L}_{c}^{s}=\sum_{i} L_{i c} \quad c=s k \cup u n,
$$

where $L_{i c}$ represents the $c$ different labour categories employed in sector $\mathrm{i}$.

\section{(b) Labour Market Equilibrium and the Exogenous Real Wages Hypothesis}

Under the hypothesis that real wages of skilled workers ( $\mathrm{sk}$ ) and of basic skilled workers (bk) are exogenous, I assume that the supplies of labour of each categor $\mathrm{y}, \bar{L}_{l}^{s}$, is fixed, and that the real wages are binding, thus bring-

5. In this study, 8 labour categories are distinguished in 3 skilled workers (sk) and 5 unskilled workers (un). In turn, the latter group is distinguished in 4 basic skilled workers (bk) and 1 non-skilled workers (nk).

6. The impact of the $\mathrm{CU}$ on Turkish internal migration is examined by De Santis [1998]. 
ing about unemployment in each occupational group, $\mathrm{U}_{\mathrm{l}}$ :

$$
U_{l}=\bar{L}_{l}^{s}-\sum_{i} L_{i l} \quad l=s k \cup b k,
$$

where $L_{i l}$ represents the I different labour categories employed in sector $i$. The wage equation for a given occupational category $I, w_{1}$, takes the following form:

$$
w_{l}=\bar{w}_{l} P,
$$

where $\bar{w}_{l}$ is the fixed real wage and is the endogenously determined wholesale price index.

\section{(c) Labour Market Equilibrium and the Wage Curve Hypothesis}

As estimated by Blanchflower and Oswald [1994] for several developed countries, and by Hoddinott [1996] for Cote d'Ivoire, a low-income economy with a 1995 per capita GN P equal to one fourth that of Turkey, the elasticity between wage and unemployment approaches -0.1. Unfortunately, no one has estimated this relationship for Turkey; nevertheless in the 'wage curve' scenario, I assume that the Turkish labour market, with the exception of farmers, is characterised by a long-run negative relationship between the wage rate and unemployment. ${ }^{7}$ Then,

$$
\begin{aligned}
& U_{l}=\bar{L}_{l}^{s}-\sum_{i} L_{i l}, \\
& \frac{w_{l}}{P}=\Gamma_{l} U_{l}{ }^{\prime}, \quad{ }_{l}<0, \Gamma_{l}>0 .
\end{aligned}
$$

Note that the negative relationship between wage rate and unemployment can be theoretically explained with the 'efficiency wage' hypothesis or with

7. The unemployment rate in Turkey was in the range of $6.6 \% 9 \%$ in the period 1988 1995. In particular, the unemployment rate ranged between $10 \%$ and $13.7 \%$ in urban areas, and between $3.9 \% 5.9 \%$ in rural areas, which implies that official unemployment in Turkey is largely confined to the non-agricultural sector. However, it must be said that the disguised unemployment in rural areas is not captured by the official employment figures. Nevertheless, this paper assumes that farmers are always fully employed.

8. For example, it can be argued that low unemployment strengthens the labour bargaining position relative to that of employers and so yields equilibria with higher wages. For a detailed discussion, see Blanchflower and Oswald (1994). 
bargaining models between firms and trade unions. ${ }^{8}$ Thus, (3c) should not be treated as an ad hoc specification. These three hypotheses for the Turkish labour market result in three alternative scenarios.

\section{B. Treatment of Traded Goods and F oreign Sector Closure}

\section{(a) Imports}

As far as the imports are concerned, on the supply side, the small country assumption is postulated with respect to both regions. On the import demand side, a three stage nested separable CES function is employed. Thus, it is assumed that both consumers and entrepreneurs first decide between composite commodities, then decide between domestically produced goods and the composite imported commodities, and then choose between imports from the EU, $M_{i}^{E U}$, and imports from the RoW, $M_{i}^{R o W}$, with elasticity of substitution $\mu_{\mathrm{i}}$, according to the Armington specification, which states that products of different countries competing in the same market are imper fect substitutes:

$$
\begin{aligned}
& M_{i}^{E U}=A_{i}^{-1}\left\{i_{i}^{-1}+i^{i-1}\left(1-{ }_{i}\right)^{i}\left[\frac{\overline{p w m}_{i}^{R o W}\left(1+t_{i}^{R O W}\right)}{\overline{p w m}_{i}^{E U}\left(1+t_{i}^{E U}\right)}\right]^{1-}\right\}^{i} M_{i}^{C}, \\
& \left.M_{i}^{R o W}=A_{i}^{-1}\left\{\left(1-i_{i}\right)^{-1}+i_{i}{ }^{(1-}{ }_{i}\right)^{i-1}\left[\frac{\overline{p w m}_{i}^{E U}\left(1+t_{i}^{E U}\right)}{\overline{p w m}_{i}^{\text {RoW }}\left(1+t_{i}^{\text {RoW }}\right)}\right]^{1-i}\right\} \quad M_{i}^{C},
\end{aligned}
$$

where $\overline{p w m}_{i}^{E U}$ and $\overline{p w m}_{i}^{R o W}$ are the fixed world prices of similar imports produced by the EU and the RoW, respectively; and $t_{i}^{E U}$ and $t_{i}^{\text {RoW }}$ are the applied ad valorem regional import tariff rates, gross of the applied ad val orem M ass Housing Fund levies on EU and RoW commodities evaluated in terms of tariff equivalent; ${ }^{9} M_{i}^{C}$ denotes the composite imports; $\mathrm{A}_{i}$ and $\alpha_{i}$ are the shift and the share parameters of the CES import aggregation function.

9. Turkey has levied this surcharge on imports since 1984, the year of the Housing Fund law approved by the Turkish Parliament to finance the government's low cost housing scheme for poor and middle-class income households. The M ass Housing Fund duty has been phased out in 1998 (GATT, [1994]). 
The acceptance of the $1996 \mathrm{CU}$ protocol implies that for mining and industrial products $t_{i}^{E U}$ has to be set equal to zero $t_{i}^{R o W}$ and has to be set equal to the European common external tariff. The modification of tariff rates leads to a change in relative prices, which will affect the demand of imports and, at the upper level, the demand of the domestically produced goods and the demand of composite goods.

\section{(b) Exports and VERs}

With regard to exports, on the demand side, the small country assumption implies the export demand functions to both regions to be infinitely elastic. Hence, the Turkish export production is totally absorbed by foreign trade partners at world prices. However, for goods subject to VERs, the domestic supply price of exports, $p e_{i}^{E U}$, is endogenously determined by the amount of output which is agreed to be exported. Hence,

$$
p e_{i}^{E U}=\frac{\overline{p w e} e_{i}^{E U}}{1+q_{i}^{E U}}
$$

where $\overline{p w e}_{i}^{E U}$ is the fixed price of exports prevailing in the EU market, and $q_{i}^{E U}$ represents the ad valorem export quota premium parameter on Turkish textiles and apparel. When $q_{i}^{E U}$ is zero, the domestic supply price of exports to the $E U$ is equal to the price prevailing in the $E U$ market. This implies that Turkey captures the rents on textiles and wearing apparel, $V E R_{i}^{E U}$. These quota rents are allocated to the Turkish exporting sectors, ${ }^{10}$ and then transferred to households, proportional to the agreed quota premium and the level of exports:

$$
V E R_{i}^{E U}=q_{i}^{E U} p e_{i}^{E U} E_{i}^{E U} .
$$

On the supply side, the export supply functions to the $E U, E_{i}^{E U}$, and the RoW, $E_{i}^{R o W}$, are derived by maximising total export sale revenues subject to the export possibility frontier, $E_{i}^{C}$, which is defined by a constant elasticity

10. Since the Turkish government does not officially recognise any quota restriction, VERs agreements could only be made with Turkish industry associations (GATT [1994]). Thus, the rents from VERs accrued to the exporting firms which were able to obtain the export quota documents for deliveries to the EU. 
of transformation (CET) function. The EU does not levy any tariff on Turkish mining and manufacturing exports. Hence,

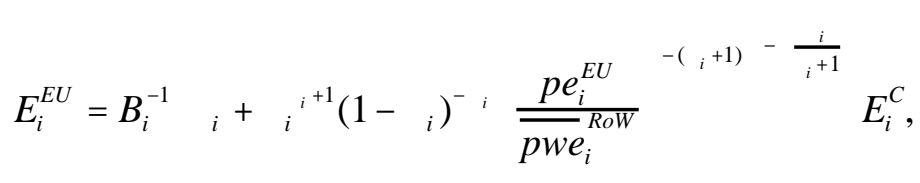

$$
\begin{aligned}
& E_{i}^{\text {Row }}=B_{i}^{-1}\left[\left(1-{ }_{i}\right)+\bar{i}^{-i}\left(1-{ }_{i}\right){ }^{i+1}\left(\frac{\overline{p w e}_{i}^{R o W}}{p e_{i}^{E U}}\right)^{-\left({ }_{i}+1\right)}\right\rceil^{-\left(\frac{i}{i+1}\right)} E_{i}^{C},
\end{aligned}
$$

where $\overline{p w e}_{i}^{R o W}$ is the fixed price of exports prevailing in the RoW market, $\eta_{i}$ the elasticity of transformation, $B_{t}$ and $\beta_{i}$ the shift and the share parameters of the CET export aggregation function. The composite export, $E_{i}^{C}$, is in turn derived by maximising total sales (domestic sales, plus export sales) subject to the production possibility frontier, which is a transformation function of the domestic good and the composite export with constant elasticity.

With the implementation of $\mathrm{CU}$ agreement, $q_{i}^{E U}$ is zero, the quota rents disappear and $p e_{i}^{E U}=\overline{p w e}_{i}^{E U}$. This will affect sectoral exports and domestic production decisions.

\section{(c) Foreign Sector Closure}

The current account deficit, $\overline{C A}$, is exogenously specified. Thus, the equilibrium in the balance of payments is:

$$
\sum_{i} \overline{p w e}_{i}^{E U} E_{i}^{E U}+\sum_{i} \overline{p w e}_{i}^{R o W} E_{i}^{R o W}+\overline{C A}=\sum_{j} \overline{p w m}_{j}^{E U} M_{j}^{E U}+\sum_{j} \overline{p w m}_{j}^{R o W} M_{j}^{R o W} .
$$

\section{Households' Revenues and Consumption}

\section{(a) Households' Revenues}

The household sector comprises 20 urban and 19 rural household groups classified according to their income level. This disaggregation allows one to identify the losers and the gainers of the $\mathrm{CU}$ agreement between Turkey and the EU. The source of private income, $H R_{h}$, originates from wage payments, returns to capital, plus rents from VERs: 


$$
H R_{h}=\sum_{c}{ }_{h c}^{L} \sum_{i} w_{c} L_{i c}+{ }_{h}^{a g r} \sum_{a g r} r A K_{a g r}+{ }_{h}{ }_{h} a g r\left(\sum_{n a g r} r A K_{\text {nagr }}+\sum_{i} V E R_{i}^{E U}\right),
$$

where $A K_{\text {agr }}$ and $A K_{\text {nagr }}$ denote the capital factor in agricultural (agr) and non-agricultural (nagr) activities ( $i=a g r \cup$ nagr), respectively; $r$ and $w_{c}$ are the returns on capital and labours of different skills' categories, respectively; ${ }_{h c}^{L}$ represents the distributive share parameters of labour income to households; and ${ }_{h}^{a g r}$ and ${ }_{h}^{n a g r}$ represent the distributive share parameters of agricultural and non-agricultural capital incomes to households, respectively. Since the Turkish government did not take part in the VERs arrangements with the $\mathrm{EU}$, the rents accrued directly to the private companies, who then distributed them back to shareholders in the form of dividends, and therefore in proportion to ${ }_{h}^{\text {nagr }}$.

\section{(b) Households' Consumption}

Since the model is static, the households' utility functions are defined only over composite commodities. The households' consumption behaviour is obtained by maximising their utility functions, subject to their disposable income. Because of lack of data on the values of the elasticity of substitution among commodities for each household group, consumers' preferences have been described simply by Cobb-Douglas utility functions.

\section{Government Revenues and Expenditure}

The government levies various taxes in order to finance its expenditures: a direct tax on household income; duties on imported goods; and indirect taxes on goods and services. Despite the VAT system only being introduced in Turkey in 1985, VAT has become the main component of indirect tax revenues. AGE modellers usually levy the VAT rates on wage payments, plus the return to capital net of depreciation, thus assuming a proportionate tax on the value added by the firm (income tax base definition of the VAT) ${ }^{11}$

11. Harrison, et al. [1996, 1997] for example employ the VAT, defined on the income side, as a replacement tax to examine the impact of the $\mathrm{CU}$ agreement on Turkey's welfare. 
However, by definition, VAT applies to commodities' net sales of all intermediate goods purchases (consumption tax base definition of the VAT). The consumption tax base definition of VAT is an equivalent concept of the income tax base definition only if the tax rate is uniform among commodities. However, the effective VAT rates in Turkey are commodity specific. ${ }^{12}$ Hence, the consumption tax base definition of the indirect taxes has been employed as replacement tax to perform a revenue neutral tariff reform. A fuel consumption tax is also considered. Public expenditure is simply treated as exogenous consumption of public goods and services in real terms. Thus, the government is a separate consuming agent; however its consumption decisions are not affected by price changes.

\section{E. Goods Market Equilibrium}

The equilibrium in the goods market is represented by:

$$
Q_{j}=C_{j}+\sum x_{j i}+\bar{G}_{j},
$$

where $Q_{\mathrm{j}}$ denotes the Armington good, $\mathrm{C}_{\mathrm{j}}$ the consumer demand, and $\bar{G}_{j}$ public expenditures.

\section{F. Welfare and Inequality Measures}

\section{(a) Welfare Measure}

Two main indices are constructed to measure welfare changes in AGE literature: the equivalent variation and the compensating variation. Since they are very similar concepts, I use the Hicksian equivalent income variation to study the impact of the partial trade liberalisation policy on each household income group. The welfare of urban and rural household income groups, and of the Turkish nation as a whole, is an additive aggregation of the welfare of each household income group. ${ }^{13}$ One drawback of this model for the

12. The VAT system has been introduced in Turkey in 1985. As has been reported by the OECD [1992, 1994], the tax administration is still inadequate in the face of a large underground economy. Hence, despite the general VAT rate being 15\%in 1994, the effective VAT rate is not uniform among commodities. 
computation of the welfare effect in the scenarios with unemployment is the lack of the leisure-consumption choice. This is because the model assumes that all 39 households employ their members in 8 different labour categories. Therefore, a vector of leisure demand functions is difficult to determine, unless restrictive assumptions regarding forms of aggregate household income are postulated. Hence, the money metric of welfare change derived by using the utility function embedded within the model underestimates the impact on welfare, if the CU leads to further unemployment; and overestimates this effect, if the trade agreement favours the creation of new jobs. However, if the marginal welfare of leisure in Turkey is hypothesised as small, then the computed money metric of welfare can be treated as a good approximation.

\section{(b) Inequality Measure}

As far as the measurement of inequality is concerned, the study focuses on the inequality between urban and rural household members. The number of members within each household group varies substantially, and many of them are concentrated around the bottom and middle of the income distribution. This implies that considerable information would be lost if the income received by household income groups is used as a unit to measure inequality. ${ }^{14}$ Since the data source does not provide any additional information concerning the income redistribution among household members in each income class group, the arithmetic mean income across household members in each income class group, $\mathrm{hr}_{h}$, has been employed to examine the $\mathrm{CU}$ impact on the size distribution of income. However, income does not directly capture the price effect as tariffs fall. Therefore, the ratio between $\mathrm{hr}_{\mathrm{h}}$ and the "true" cost of living index, $P_{h}=\Pi_{j}\left(p_{j} /{ }_{j h}\right)^{j h}$ where ${ }_{j h}$

13. Although this procedure is widely used in cost-benefit analysis, it presents problems related to interpersonal utility comparisons, which are described in Boadway (1974).

14. Assume that there are two households groups ( 1 urban household group and 1 rural household group), each earning the same income. Obviously, income is equally distributed among household groups. Assume now that the rural household group is composed of $k$ members. In this case, income would be unequally distributed among household members. This implies that the use of the income received by household groups as a unit of measure of inequality would be imprecise. 
denotes the household budget share for good j, (that is, the indirect utility function) is used as a basis to measure inequality. ${ }^{15}$

A set of general entropy indices for discrete distributions, $G E$, has been employed to measure inequality. Given the assumption that, within each income class group, members receive the same income, $G E$ can be written as:

$$
G E=\frac{1}{{ }^{2}-}\left\lceil\frac{1}{K} \sum_{h=1}^{H}\left(\frac{k_{h} h r_{h} / P_{h}}{h r^{m}}\right)-1\right\rceil \quad K=\sum_{h=1}^{H} k_{h},
$$

where $k_{h}$ represents the number of household members in each household income group $\mathrm{h} ; \mathrm{K}$ the total number of members; $\mathrm{hr}^{\mathrm{m}}$ the arithmetic mean income across household members for the entire population in real terms; $H$ the number of household income groups, which is 39 (i.e. 20 urban and 19 rural household income groups); and $\theta$ an arbitrary parameter which in principle can assume any real value, although particular values generate known inequality measures. The generalised entropy index measures the average distance between each person's real actual income and the real income $\mathrm{s} /$ he would receive in a perfectly equal society. The advantage of this is that one can derive the inequality measure directly, without postulating the existence of a social welfare function, and discussing its desired properties (Cowell [1995]). The generalised entropy index has also been chosen as an indicator of income inequality because it has three main important properties: it satisfies the strong principle of transfer, according to which the change in inequality depends only on the "distance" between individual income shares, no matter which individuals one chooses; it is additively decomposable by population subgroups; and it encompasses all other measures that are ordinally equivalent: the entire subfamily of Atkinson indices $(\theta<1)$, the Theil index $(\theta=1)$ and half of the square of the coefficient of variation $(\theta=2) .{ }^{16}$ In general, a large positive value for the parameter

15. It must be stressed that household income does not adjust for differences in needs between households (so called equalisation process), but only for the number of individuals (so called reweighting process). A fuller discussion on these issues can be found in Cowell [1984], Danziger and Taussig [1979], and Glewwe [1991].

16. For proof and further discussion see Bourguignon [1979], Cowell [1980], Cowell and Kuga [1981a, 1981b], Shorrocks [1980]. 


\begin{tabular}{|c|c|c|c|}
\hline & 起咅 & 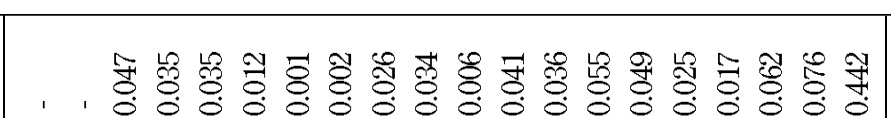 & \\
\hline & 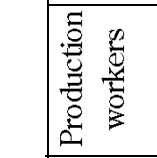 & 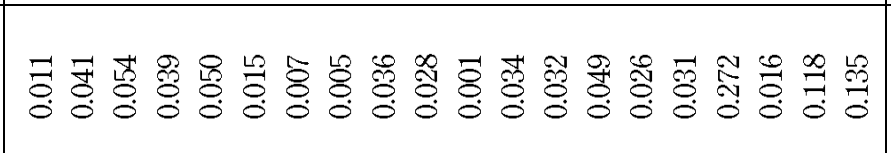 & \\
\hline 然 & 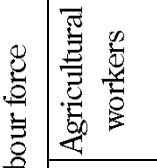 & , , , , , , , $8,8,8$ & \\
\hline & 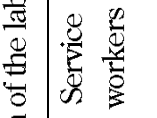 & 웅 & \\
\hline$\stackrel{1}{3}$ & 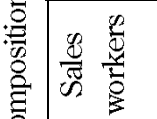 & 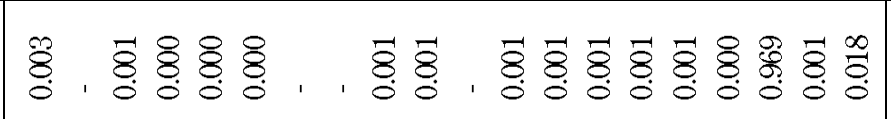 & \\
\hline$\frac{15}{9}$ & 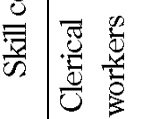 & 융 형영 잉 & \\
\hline 密 & 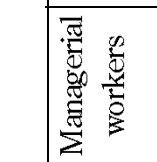 & 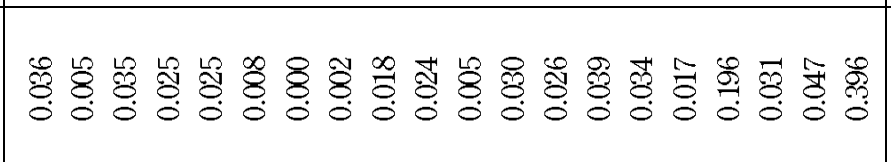 & $\xi$ \\
\hline 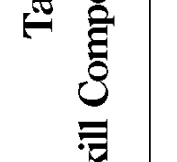 & 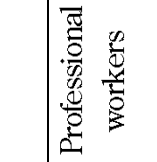 & 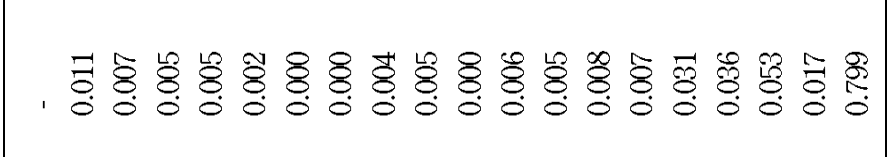 & $\xi$ \\
\hline है & 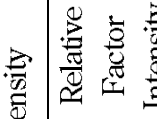 & 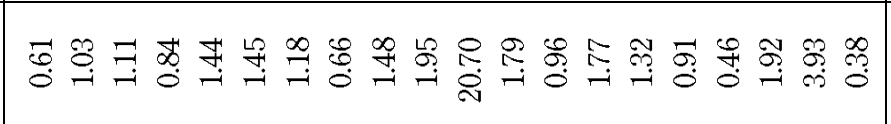 & \\
\hline 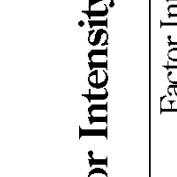 & 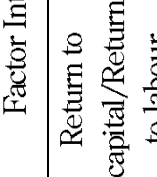 & 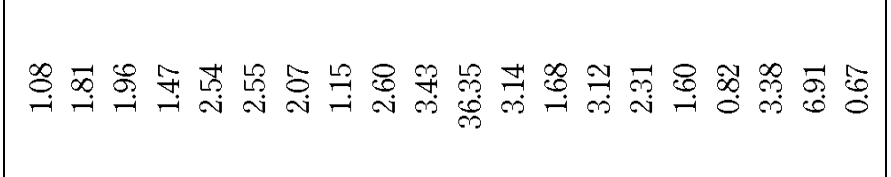 & 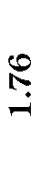 \\
\hline 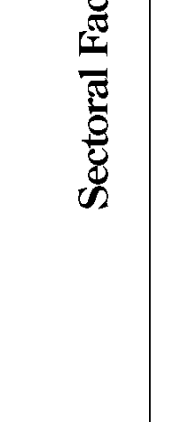 & & 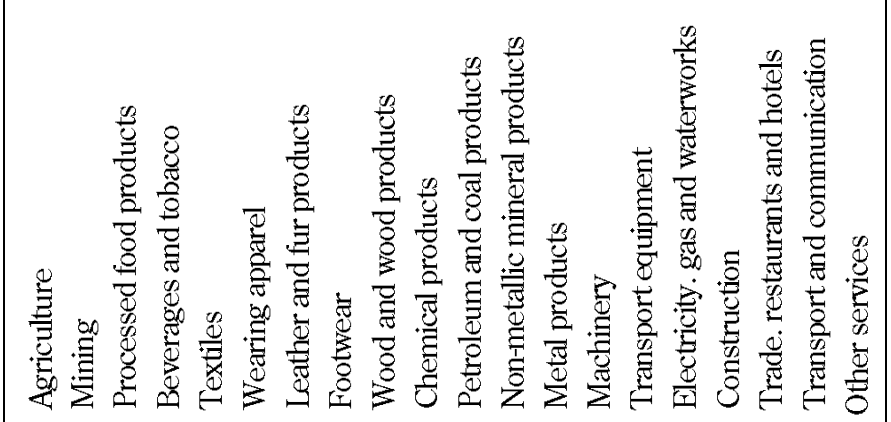 & \\
\hline
\end{tabular}


$\theta$ indicates that the measure is sensitive to income differences at the top end of the income distribution (i.e. top sensitive inequality measure). Similarly, measures with negative values of $\theta$ indicate that the measure is sensitive to income differences at the bottom end of the income distribution (i.e. bottom sensitive inequality measure). The additive decomposability property is very important for this study because one can compare the inter group income inequality among rural and urban areas and the inter group income inequalities among household members partitioned according to their geographical location.

\section{Features and Properties of the Benchmark}

The benchmark data set employed to calibrate the relevant variables and parameters of the model is mainly based on a 1990 Social Accounting M atrix (SAM) for Turkey, constructed for the year 1990 by De Santis and Ozhan [1995, 1997], and consistent with the data published in the official Input-Output (I-O) table by the State Institute of Statistics of Turkey (SIS, [1994]). ${ }^{17}$ The main feature of this SAM is that it incorporates information from household income and consumption expenditures surveys, as well as from household labour surveys. Factor payments are mapped from income data onto the thirty-nine household income classes, so establishing the link between the functional and the size distributions of income. Hence, this SAM is a ver $y$ useful data set for income distribution analysis. ${ }^{18}$

The I-O table and the SAM for Turkey define the cost of labour in terms of wages and salaries (i.e. compensation of employees) and the operating surplus as a balancing residual. This implies that agriculture, which is dominated by self-employed and unpaid family labour, would be characterised by

17. The calibration procedure consists of estimating unknown parameters, such that the observed values of endogenous variables constitute an equilibrium of the numerical model. It is important to stress that the numerical calibration does not involve any econometric testing procedure.

18. This SAM has been also used by Harrison, et. al [1996, 1997]. Thus, given the same main structure of the data set and the similar modelling approach, their results on aggregate welfare, sectoral production and indirect taxation are comparable with those reported in this study. 
an underestimated ratio between labour and capital. In fact, according to the I-O table and the SAM , the ratio between gross operating surplus (that is, operating surplus plus consumption of fixed capital) and compensation of employees in agriculture, animal husbandry, forestry and fisheries is on average equal to 7.92 and 8.87 , respectively. Since this might affect the computation of the impact of the CU agreement on the size and the functional distribution of income, I have calculated the total farmers' earnings in Turkish agriculture for the year 1990, by using as a basis the average nominal wage in agriculture estimated by Bulutay for the year 1989 (Bulutay [1995]). ${ }^{19}$ According to my estimates for agriculture, the ratio between farmers' earnings and value added is $45.01 \%$ and the ratio between total labour cost and value added is $48.09 \%$ Similarly, the ratio between the gross operating surplus and compensation of employees cannot represent the capital/ labour ratio for several manufacturing industries. Thus, I have computed this ratio for most sectors by using the official value added figures and the annual gross payments to employees published by the SIS for the year 1990 (SIS [1998]). Table 1 reports the estimated capital/ labour ratio used in this study, the relative factor intensity measure for each sector and the sectoral skill composition of the labour force.

Table 2 shows the share of Turkish exports to the EU and the share of Turkish imports from the EU provided by Harrison, et al. [1996]; and the nominal protection rates estimated by Togan for the year 1994 (Togan [1997]). The ad valorem tariff rates have been weighted by using 1990 import volume weights. The last column of Table 2 indicates the average ad valorem tariff rates, which will be adopted by Turkey around the year 2001. They are an average of the GSP and MFN rates computed under the assumption that the share of Turkish goods imported from countries having GSP treatment with the EU is $27.54 \%$ and the share of Turkish goods imported from countries for which the EU applies the common external tariff is $25.24 \%$ (see Togan [1997]). The duties levied by the EU on Turkish

19. I have also considered the fact that the index of prices received by farmers increased by $62.8 \%$ from 1989 to 1990 (SPO [1996], and that the full time equivalent work in agriculture is $41 \%$ of the entire time, as has been estimated for similar European Mediterranean countries (EC [1996]). 


\begin{tabular}{|c|c|c|}
\hline \multirow{9}{*}{ 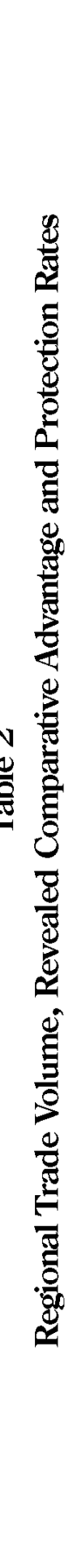 } & 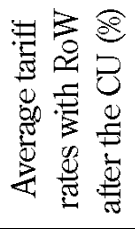 & 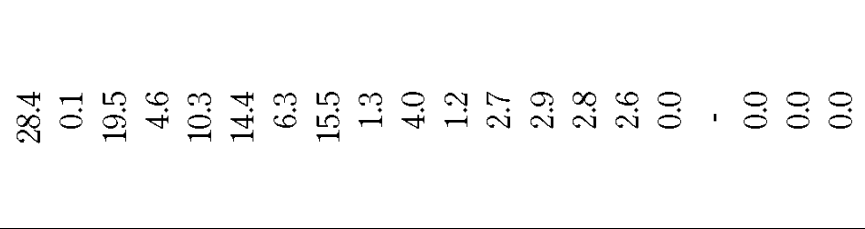 \\
\hline & $\begin{array}{l}\text { 票 } \\
\text { 空 }\end{array}$ & 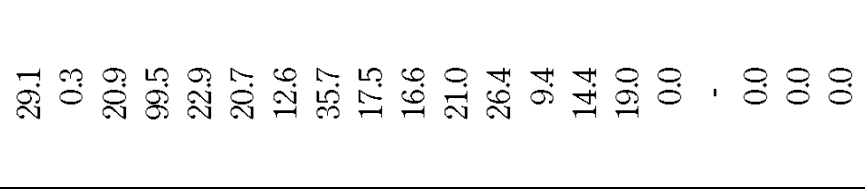 \\
\hline & 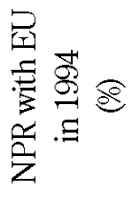 & 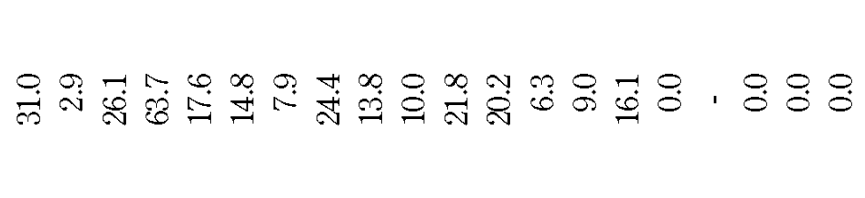 \\
\hline & $\overleftrightarrow{\mathscr{Z}}$ & 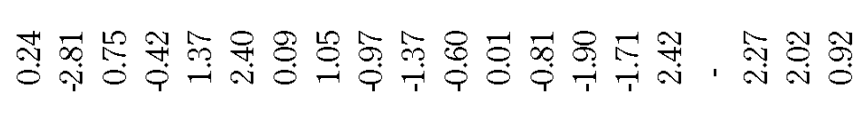 \\
\hline & 蒙总 & 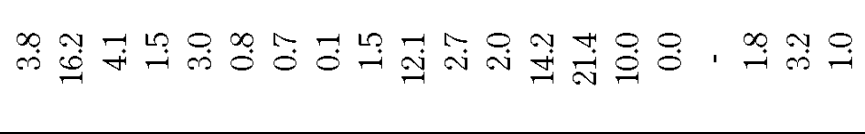 \\
\hline & 离总 & 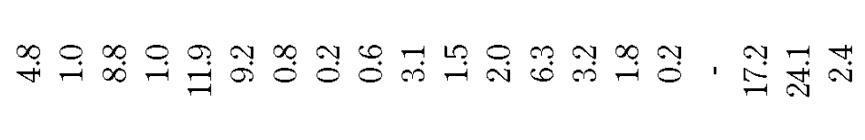 \\
\hline & 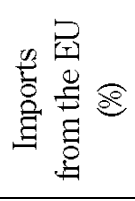 & 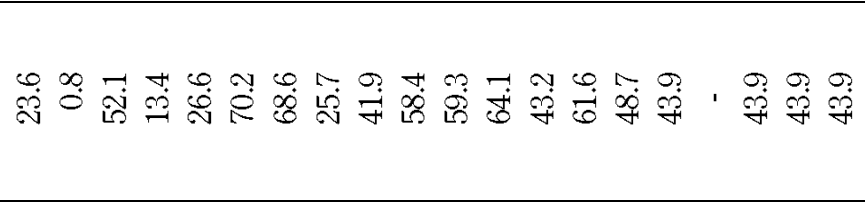 \\
\hline & 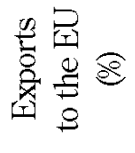 & 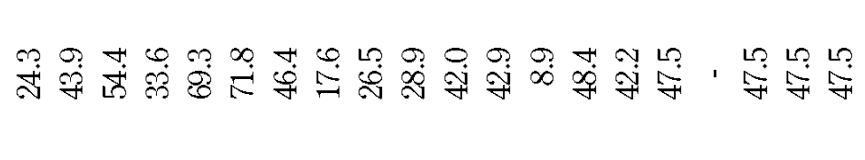 \\
\hline & & 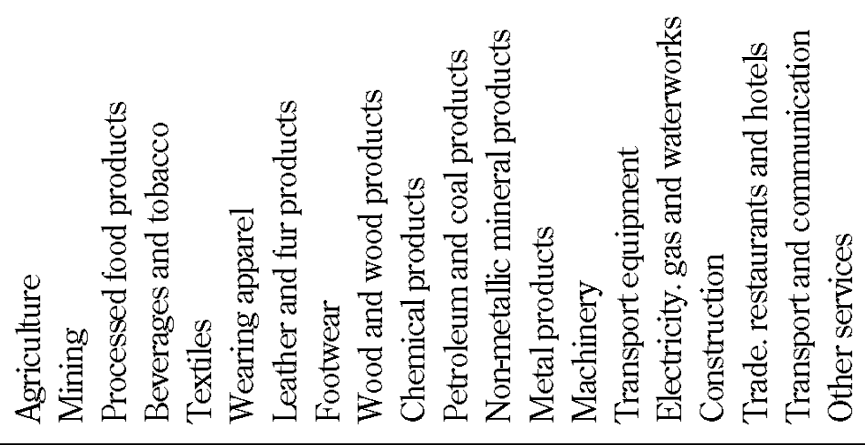 \\
\hline
\end{tabular}


imports not subject to the CAP are zero. Regarding the quota restriction on Turkish textiles and wearing apparel exports to the EU, the exogenous increase on the export price of these goods, used by Harrison, et al. [1996, 1997], is assumed to be the ad valorem quota premium on VERs. For the subsequent analysis on welfare, note that the average tariff rates, which will be levied by Turkey on non-member states imports after the $\mathrm{CU}$, are lower than the applied tariff rates now levied on goods imported from the RoW. This implies that the $\mathrm{CU}$ should not be trade diverting. ${ }^{20}$

As shown in Table 2, exports originating from textiles, wearing apparel, food processing and metal products constitute $36.2 \%$ of total exports and $72 \%$ of total manufacturing exports. In particular, textiles and wearing apparel comprise $21.1 \%$ of total exports and $41.9 \%$ of total manufacturing exports. These statistics give an indication of the products for which Turkey has a comparative advantage in trade. In fact, the manufacturing activities with more that 5\%export share, and which have a positive revealed comparative advantage (RCA) value, are processed food products, textiles and wearing apparel. These are the sectors which should expand with trade liberalisation. ${ }^{21}$ Regarding imports, four manufacturing industries (chemical products, metal products, machinery and transport equipment) comprise 57.7\% of total imports, and $78 \%$ of total manufacturing imports. These sectors are also moderately protected, therefore they should contract with the $\mathrm{CU}$ agreement.

20. Turkey will also negotiate preferential trade agreements with third countries, with whom the EU has negotiated Association and Free Trade agreements. Harrison, et al. [1996, 1997] have increased the price of all manufacturing goods to the RoW by $4.2 \%$ as a proxy for a better access to third markets. However, since many countries (the Lome convention countries, the Central and Eastern European countries, the M editerranean countries, etc.) will be involved, then, with our current knowledge, it is impossible to compute the percentage price increase at both sectoral level and as an average value. Any speculative assumption might compromise the results of the simulations on sectoral output, welfare and income distribution. Hence, the better access to third countries is ignored.

21. RCA is measured by $\ln \left[\left(E_{i} / M_{i}\right) /\left(\sum_{i} E_{i} / \sum_{i} M_{i}\right)\right]$. By using the same formula, similar RCA values for Turkish manufacturing industries have been estimated by Celasun [1994] for the period 1987-1989 and by Togan [1994] for the period 1989-1990. 


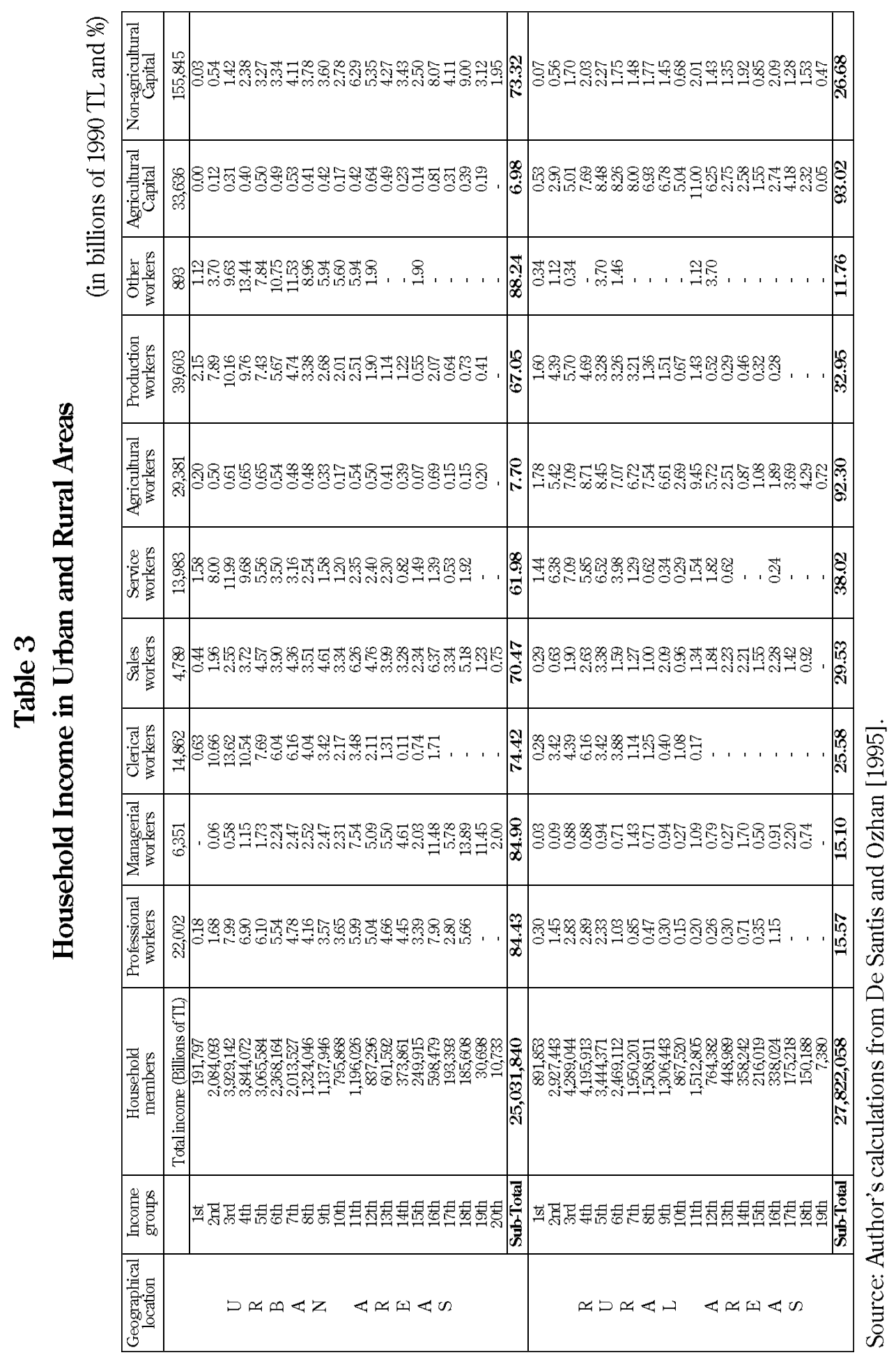


Table 3 shows the source of income of urban and rural households, disaggregated by their income size and split into twentieth duodeciles, obtained from the 1987 Turkish household income and consumption expenditure survey (De Santis and Ozhan [1995]). Each income class group contains a large number of household members. In aggregate, the geographical subgroups are composed of about 25 million urban household members and almost 28 million rural household members. It is evident that much of the urban and rural population is concentrated in the bottom-middle of the income distribution. In fact, $87.7 \%$ of urban household members (almost 22 millions) and $91.2 \%$ of rural household members (almost 25 millions) earn an income level below the eleventh duodecile. In addition, $69.8 \%$ of labour income and $55.2 \%$ of capital income is allocated among urban household members, which represent only $47.4 \%$ of the population. This implies that intra-group income inequality, as well as inter-group income inequality, are important features of Turkey. It is also interesting to note, for the subsequent numerical analysis on income inequality, that the main income source of rural households is agricultural labour and capital incomes. A contraction (expansion) in agriculture would imply a fall (rise) in rural welfare and a rise (fall) in inter-group income inequality.

In the scenarios with unemployment, I assume that the unemployment rate in each occupational category is equal to the average manufacturing unemployment rate in Turkey, which was around 11\% in the first half of 90's. Total labour demand is given by the benchmark, whilst exogenous total labour force is endogenously calibrated by adding unemployment to labour demand. This implies that the total labour force assumes different values under the full employment scenario and the scenarios with unemployment.

$W$ ith regard to the elasticity values, the factor substitution elasticities, the Armington trade elasticities, and the elasticities of transformation have been selected from Harrison, et al. [1992], and some of them have been adjusted for differences in sectoral aggregation. To capture the "skilled labour-capital complementarity" hypothesis, I assume that ${ }_{i}=0.75{ }_{i}$. The elasticities of substitution among skilled and unskilled labour categories are assumed to be equal to 2 and 5 , respectively. With regard to the elasticity of the 'wage curve', because of the lack of data, I assume that the evidence reported by Blanchflower and Oswald [1994] for several developed countries, and by 
Hoddinott [1996] for Cote d'Ivoire, is also valid for Turkey. Thus, is set equal to - 0.1. All other parameter values, such as initial prices, factor income distribution shares, shift and share parameters of different functional forms, have been calibrated by employing the standard techniques widely used in AGE literature ( $M$ ansur and Whalley [1984]).

In summary, the SAM accounts used in this study are disaggregated as follows: factor labour is disaggregated into 8 different types of labour categories; ${ }^{22}$ households are disaggregated according to their income size and their geographical regions ( 20 rural and 19 urban households); activities and commodities are disaggregated into 20 different types and classified according to the I-O table classification; trade flows are disaggregated in two types, one with the EU and one with the non-member states.

\section{The Revenue-Neutral Tariff Reform Scenarios}

The preferential trading arrangement between Turkey and the EU is a regional economic integration agreement, according to which the member countries remove tariffs and quotas on mining and manufacturing commodities which circulate within the $\mathrm{CU}$, and apply a common external tariff from outside the CU. As a result, nominal protection rates on goods subject to the European CAP (that is, agricultural and processed food commodities) remain unchanged. The initial equilibrium reflects the situation that prevailed in 1994, which is based upon the protection rates reported in Table 2.

The indirect tax rate has been used as a policy instrument manoeuvrable by policy-makers to perform a revenue-neutral tariff reform. This experiment has been carried out under three alternative hypotheses: firstly, real wages are assumed to be flexible and full employment is maintained in each occupational category (scenario labelled 'Flexible wages'); secondly, real wages are assumed to be sticky (with the exception of farmers' wages),

22. Partly following Wood (1994), I classify professional workers, managerial workers and clerical workers as the skilled labour group, with post-basic education; sales workers, service workers, non-agricultural workers and other workers as the unskilled labour group, with basic education; and the agricultural workers as the no skilled labour group, with virtually no schooling. 
which implies that the effects of trade are manifested in changes in employment (scenario labelled 'Fixed wages'); and, thirdly, real wages (with the exception of farmers' wages) are assumed to adjust to the unemployment level in each occupational category (scenario labelled 'Wage curve'). The welfare effects of these scenarios are not comparable because of the lack of the leisure-consumption choice, due to the particular specification of the model, which, in order to study the impact of the $\mathrm{CU}$ on the size distribution of income, assumes that all households employ their members in 8 different labour categories. Usually, AGE modellers assume full employment of factors of production and flexible factor returns. However, I believe that this approach might misrepresent the Turkish economy, which during the first half of ' 90 s was characterised by an urban unemployment rate of $10-13 \%$ Obviously, the numerical findings must be cautiously interpreted, and are valid only in the light of these three scenarios.

\section{A. The Overall E conomic I mpact}

Before I discuss the results in detail, it is useful to understand graphically what happens at the economy as a whole, by studying the impact of the $C U$ agreement on factor costs, producer prices, primary factor inputs and GDP. It is well know from trade theory that under perfect competition, constant returns to scale and full employment of factors of production, trade liberalisation leads to both higher GDP and higher returns to the factor which is intensively used in the less protected sectors. The results presented in Table 4 and depicted in Figure 2 suggest that the CU agreement raises GDP by $3 \%$ and shifts both the labour and capital demand schedules to the right, pushing real factor prices, in particular agricultural wages being the primary sector protected, upwardly. The aggregate results of the full employment scenario are, therefore, consistent with trade theor $y$.

The results of the scenarios with unemployment are based upon the assumption that full employment is maintained among the agricultural workers; whereas unemployment is postulated among the non-agricultural workers. If the real non-agricultural wages are fixed, the increased demand for labour, due to the $\mathrm{CU}$, pushes the nominal non-agricultural wages up by $0.6 \%$ However, since real wages are constant, the producer price index 


\section{Table 4}

The Impact on Factor Costs, Factor Inputs and GDP in Real Tems

(percentage variation)

\begin{tabular}{|l|c|c|c|}
\hline & Flexible wages & Fixed wages & Wage curve \\
\hline Agricultural wage & 1.9 & 2.3 & -2.4 \\
\hline Non-agricultural wage & 0.7 & 0.0 & 0.7 \\
\hline Rent & 0.7 & -0.5 & 1.2 \\
\hline GDP & 0.3 & 0.0 & 0.5 \\
\hline Labour & 0.0 & -0.9 & 0.4 \\
\hline Capital & 0.0 & 0.0 & 0.0 \\
\hline
\end{tabular}

ought also to rise by the same percentage [see (3b)]. Since the world prices of exports are given, an increase in producer prices can be obtained if, and only if, domestic prices rise, bringing about a fall in aggregate domestic demand. ${ }^{23}$ As a result of the output fall, in equilibrium, labour demand and capital demand schedules of the non-agricultural sectors shift downward causing a $0.9 \%$ loss in jobs. Some resources, in particular the capital factor, move to the agricultural sector, whose capital stock increases by $3 \%$ The expansion of agriculture raises the demand for labour and, as a result, it pushes up the real agricultural wages by $2.3 \%$ Note that GDP in real terms remains constant. This implies that the positive effect of the trade liberalisation is offset by the negative effect of the endowment fall.

In the wage curve scenario, the negative relationship between real nonagricultural wages and unemployment implies an upward-sloping labour supply schedule. As a consequence of the right-shift of the labour demand schedule, due to the $\mathrm{CU}$ agreement, real non-agricultural wages move upward by $0.7 \%$ and employment increases by $0.4 \%$ The positive effect of the $\mathrm{CU}$, plus the positive effect of the endowment rise, bring about an increase in GDP of $0.5 \%$ The expansion of manufacturing and services raises the demand for capital, which however is fixed in supply. As a result, although

23. As shown in (6), the domestic supply prices of textiles and apparel exports will increase. However, this sectoral effect is not sufficient to increase the producer price index, because textiles and apparel exports are a small fraction of the entire Turkish production. 
Figure 2

The Impact of the CU on Turkish Factor Prices and Primary Factor Inputs

Flexible Wages Hypothesis

Non Agriculture

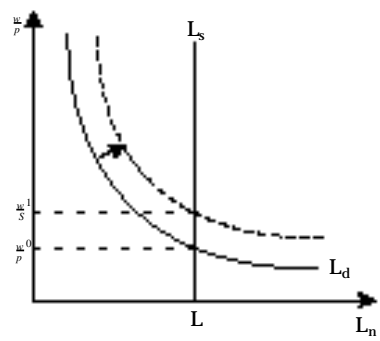

Non Agriculture

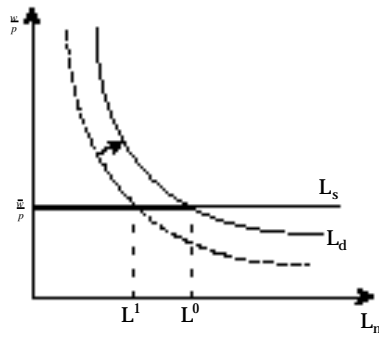

Non Agriculture

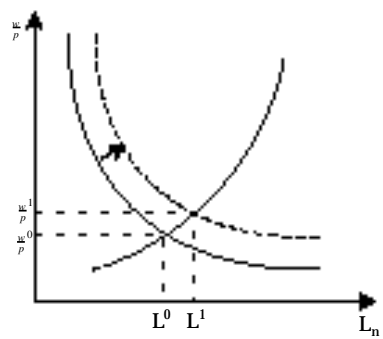

Agriculture

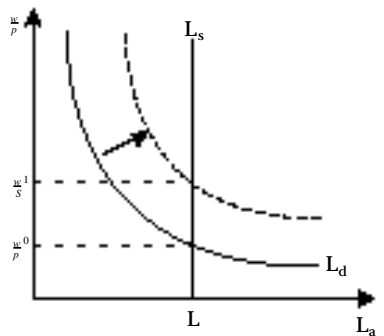

Flexible Wages Hypothesis

Agriculture

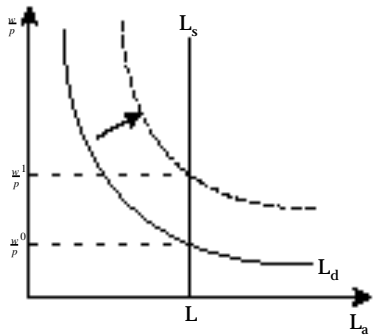

Wage Curve Hypothesis

Agriculture

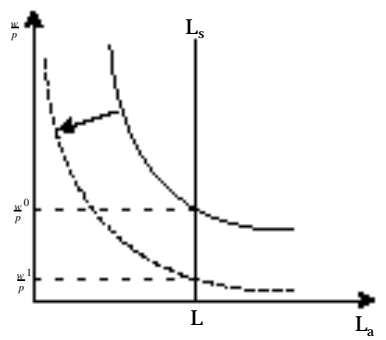

Whole Economy

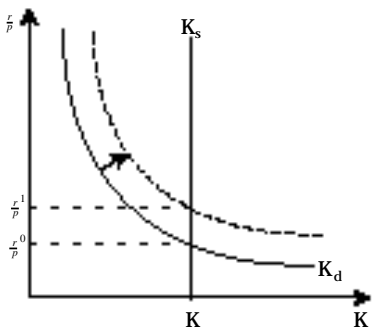

Whole Economy

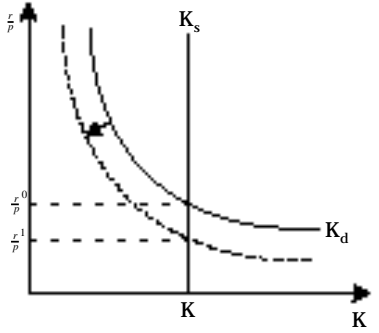

Whole Economy

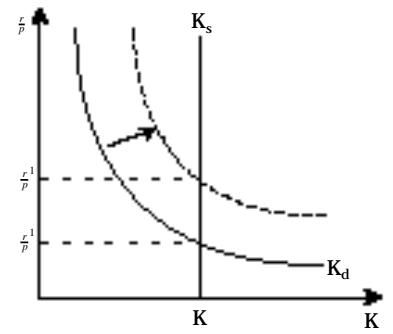

real rents increase by $1.2 \%$ some of the resources are pulled out from agriculture. In fact, the capital stock employed in the primary sector declines by $3.8 \%$ The contraction of this sector causes the downward shift of the labour demand schedule, which leads to lower agricultural wages $(-2.4 \%$. It is 
important to remember that, the benchmark value of the total labour force is larger under the scenarios with unemployment. Therefore, the results of the scenarios which assume some form of labour market rigidities are not fully comparable with those obtained under the flexible wage hypothesis.

\section{B. The I mpact on Sectoral Output and Value Added}

Regarding the impact at sectoral level, Tables 5 and 6 show that the partial trade liberalisation policy favours the expansion of manufacturing industries. Regardless of the assumption postulated for the labour market, the major growth sectors are textiles $(4.8 \%-22 \%)$, wearing apparel $(8.1 \%$ $17.8 \%$, leather and fur products $(15.7 \%-24 \%$, where Turkey has a comparative advantage and is in a position to compete with foreign countries, in particular with the European member states. Chemicals and transport equipment contract, and this is in accordance with the discussion presented in the previous paragraph, where the RCA values for each tradable commodity have been presented. ${ }^{24}$ Given the stock of capital and the assumption that it is mobile among sectors, an expansion of the manufacturing industry as a whole implies a lower capital stock, which is now available for agricultural activities and, as a result, a possible fall in agriculture. Hypothetically, one would expect an expansion of agriculture and services relative to industry seeing that the former sectors are still protected. However, this is not necessarily the case in a model where intermediate inputs used by the industrial sectors are also imported. In addition, one has to consider the fact that the trade balance is always in equilibrium. If trade liberalisation implies an increase in the import volume, the value of export sales has to rise to equilibrate the balance of payments. Given the specification of the export supply functions and the fact that manufacturing goods comprise most of exports (see Table 2), manufacturing export sales increase, boosting the industry as a whole. Hence, despite industrial products losing their protection, the value added of manufacturing expands by $0.9 \% 4.1 \%$ for two reasons: (i) it has a positive RCA, (ii) imported intermediate inputs by industries are cheaper.

A large expansion of manufacturing export sales, together with the bal-

24. Similar results at sectoral level have been obtained by Harrison, et al. [1996]. 


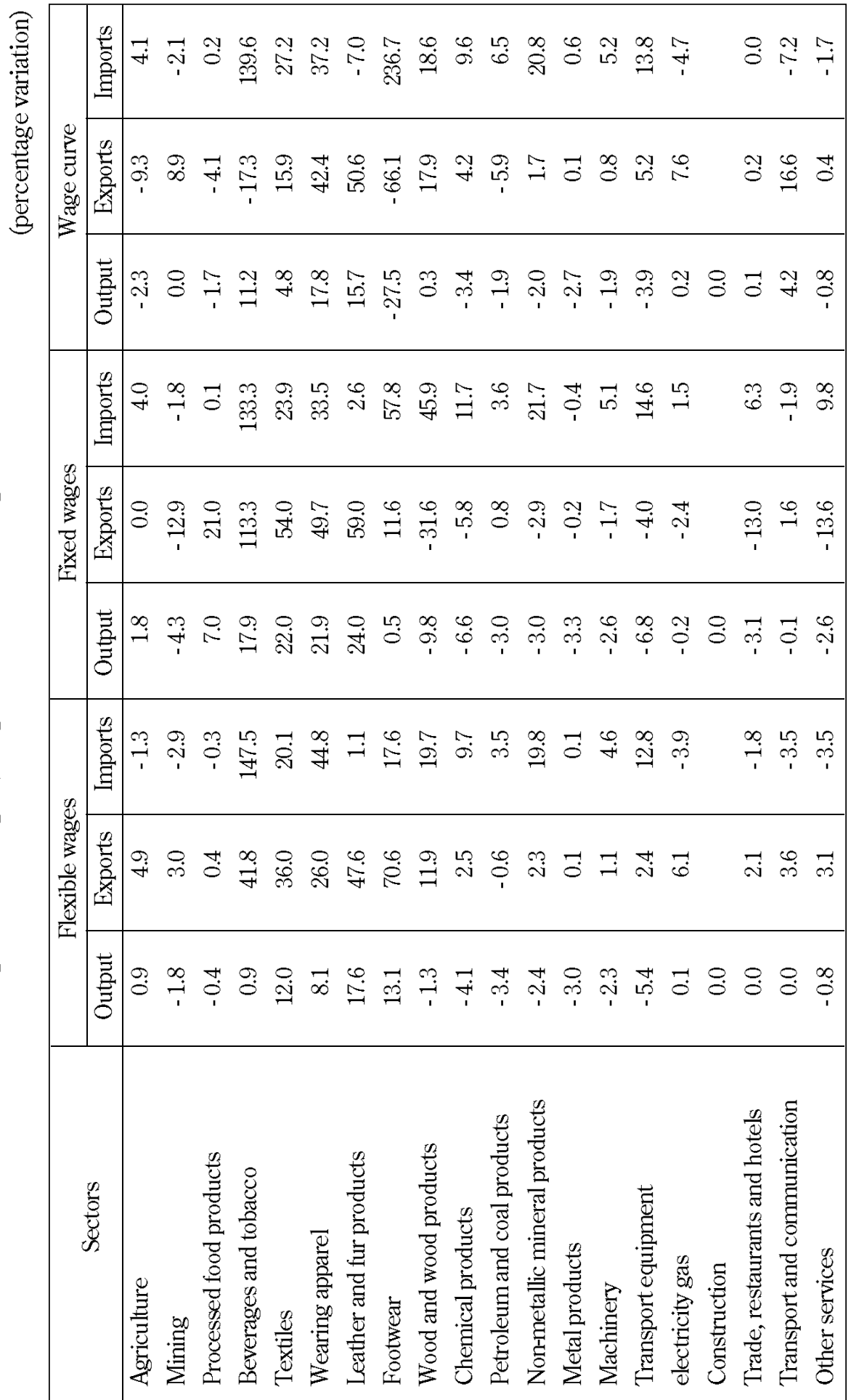


Table 6

The Impact on Output, Export Sales and Import Volume

(percentage variation)

\begin{tabular}{|l|c|c|c|}
\hline & Flexible wages & Fixed wages & Wage curve \\
\hline GDP in real terms & 0.3 & 0.0 & 0.5 \\
\hline - Agriculture & 0.5 & -0.5 & -3.5 \\
\hline - Industry & 1.2 & 4.1 & 0.9 \\
\hline - Services & -0.5 & -3.2 & 1.4 \\
\hline
\end{tabular}

ance of payment constraint and the small country assumption, might also lead to the growth of the import volume in agriculture and services. However, if the impact on the sectoral import volume is greater than that on export sales, these sectors record a decline in value added (see Table 6 and 7). In fact, the value added in agriculture increases by $0.5 \%$ in the scenario with flexible wages, where the growth rate in net agricultural trade is positive; but decreases by $0.5-3.5 \%$ in the scenarios with unemployment, where this growth rate is negative. The fact that agricultural output increases by $1.8 \%$ in the scenario with fixed real wages does not contradict the result on value added, because the output expansion is due to the $5.2 \%$ increase in real terms of agricultural intermediate demand by the textile industry, which records a large output growth $(22 \%$. The same scenario also shows a large fall in services $(-3.2 \%$. The contraction of the sector is compensated by an inflow of services from abroad (2.5\%) to satisfy aggregate demand. The comparison of the impact on services among the three scenarios is also an interesting exercise. The impact on services depends upon the effects of the CU on the rentwage ratio. Since services are less capital intensive than manufacturing, a rise in the rent-wage ratio leads to a relative higher expansion of this sector compared to manufacturing. Hence, despite the aggregate impact on GDP being modest, the value added breakdown clearly shows that resources are reallocated favouring the expansion of the Turkish industrial sectors, such as textiles, wearing apparel, leather and fur products. ${ }^{25}$

25. N eedless to say that, in the future, the liberalisation of the European CAP and the enlargement of the $\mathrm{CU}$ agreement to agricultural commodities might favour the expansion of Turkish agriculture. 


\section{The Impact on Trade F lows}

Table 7 reports the impact on trade flows. The regional agreement decreases the trade deficit with the EU by $67.8-89.6 \%$ and raises the aggregate trade volume with respect to the GDP by $7.7-9.8 \%$ The impact of the $\mathrm{CU}$ on the import volume from the $\mathrm{EU}$ and the RoW is an indicator of the Vinerian trade creation and trade diversion effects. The import volume from both regions rises, and this implies that the $\mathrm{CU}$ agreement is not trade diverting. The latter outcome is due to the fact that Turkish tariffs levied on goods imported from non-member states are bigger than the European common external tariffs. Furthermore, export sales are positively affected by the trade policy rising by $9.6-11.7 \%$ In particular, industrial exports increase by $13.8-27.2 \%$ especially toward the $E U$, thanks to the elimination of VERs in textiles and wearing apparel.

Table 7

The Impact on the Value of Trade Flows

(percentage variation)

\begin{tabular}{|l|c|c|c|}
\hline & Flexible wages & Fixed wages & Wage curve \\
\hline Trade deficit & 0.0 & 0.0 & 0.0 \\
Trade deficit with the EU & -67.8 & -89.6 & -70.8 \\
Trade deficit with the RoW & 17.4 & 23.0 & 18.2 \\
Trade volume/ GDP & 7.7 & 9.8 & 8.4 \\
Export volume & 9.6 & 11.7 & 10.7 \\
Export volume to the EU & 16.9 & 22.2 & 18.0 \\
Export volume to the RoW & 2.9 & 1.9 & 3.9 \\
Import volume & 6.8 & 8.3 & 7.6 \\
Import volume from the EU & 4.5 & 5.9 & 5.0 \\
Import volume from the RoW & 8.4 & 10.0 & 9.4 \\
Export volume in agriculture & 4.9 & 0.0 & -9.3 \\
Export volume in industry & 15.7 & 27.2 & 13.8 \\
Export volume in services & 3.0 & -5.2 & 9.3 \\
Import volume in agriculture & -1.3 & 4.0 & 4.1 \\
Import volume in industry & 7.7 & 8.9 & 8.5 \\
Import volume in services & -3.0 & 2.5 & -4.1 \\
\hline
\end{tabular}




\section{Table 8}

The Impact on Welfare

(percentage variation)

\begin{tabular}{|l|c|c|c|}
\hline & Flexible wages & Fixed wages & Wage curve \\
\hline Urban households & 0.1 & -1.2 & 1.3 \\
\hline Rural households & 1.3 & 1.3 & -0.5 \\
\hline Turkey & 0.5 & -0.2 & 0.6 \\
\hline
\end{tabular}

These results are due to the fact that intermediate demand comprises $41.7 \%$ of total aggregate demand according to the benchmark data base. As the tariff rates decline, imported intermediate inputs become cheaper and, as a result, sectors with a RCA, such as textiles and wearing apparel, can expand. The production of these sectors are, in the main, exported to the EU. Therefore, the trade deficit with this region declines. Given the trade balance equilibrium, the trade deficit with the RoW must increase, which implies that the import volume from the RoW can expand (8.4\%- $10 \%$.

\section{The Impact on Welfare}

Table 8 reports the Hicksian equivalent income variation index for urban and rural household income groups and the aggregate measures of welfare. The positive sign indicates an improvement for the households in question. They are measured as a percentage of household income. In aggregate, the welfare impact is modest, as it is typically found in most of static AGE models with perfect competition and constant returns to scale, dealing with trade liberalisation issues. ${ }^{26} \mathrm{As}$ a percentage of household income, welfare rises by $0.5 \%$ in the scenario with flexible wages, and by $0.6 \%$ in the wage curve scenario; whilst it declines by $0.2 \%$ in the scenario with fixed real

26. Harrison, et al. [1996, 1997] report an improvement of welfare equal to $0.1 \%$ of GDP (286 billions of 1990 Turkish lira) in their 'Tariff reduction' scenario with flexible wages, which is comparable to the scenario run in this study; although, they incorporate the positive effect of the preferential access agreements, which alone generates a $0.3 \%$ increase in welfare. By contrast, I estimate that welfare rises by 0.5 ( 1,661 billions of 1990 Turkish lira) as a percentage of household income. 
wages. Given the positive (negative) impact on employment, which I will discuss later in the text (see Table 11), the welfare gain (loss) in the wage curve (fixed real wages) scenario should be interpreted as an upper (lower) bound. The aggregate results of the flexible wage hypothesis are in accordance with the $\mathrm{CU}$ theory, which argues that if the trade diversion effect is relatively small and the endowment is given, then the $\mathrm{CU}$ agreement is Pareto superior.

The results on welfare become more attractive when the welfare impact is fur ther analysed within the urban and rural household income groups. In the scenario with flexible wages, the urban household group is just slightly better of, whereas the welfare gain of the rural household group is equal to $1.3 \%$ of the rural household income. In the scenario with fixed wages, urban welfare declines by $1.2 \%$ whilst the welfare gain of rural households increases by $1.3 \%$ An opposite outcome is obtained in the wage curve scenario. In this case, the rural household income group suffers an aggregate welfare loss equal to $0.5 \%$ whereas the urban household income group is better off enjoying a welfare gain of $1.3 \%$ This opposite outcome can be easily understood, if one considers the sectoral impact of the trade policy. Agricultural value added contracts by a large extent in the wage curve scenario $(-3.5 \%$, and this leads to a welfare loss among rural households.

The welfare breakdown among urban and rural households is depicted in Figures 3 and 4, respectively. Since the vector of utility functions are of the Cobb-Douglas type, the impact on welfare depends only upon the income effect and the price effect. Figure 5 and 6 show the impact of the $C U$ on the 'true' cost of living index (CLI) for each household group as defined in section [2.6.2]. A negative CLI has obviously a positive effect on welfare. Given the extraordinarily similar patterns among the CLI and the welfare of the urban group, I would suggest that the impact of the $\mathrm{CU}$ on consumer prices plays the key role in explaining the welfare effects among urban households. This result also suggests that the composition of the household budget share matrix can explain why some urban household can gain more than others. With regard to the rural household group, the same explanation can be given for the flexible wage hypothesis and, to a certain extent, for the fixed real wage hypothesis. By contrast, in the wage curve scenario, despite the fall of the CLI for all rural households, most of them lose 


\section{Figure 3}

\section{The Impact on the Welfare of the Urban Groups}

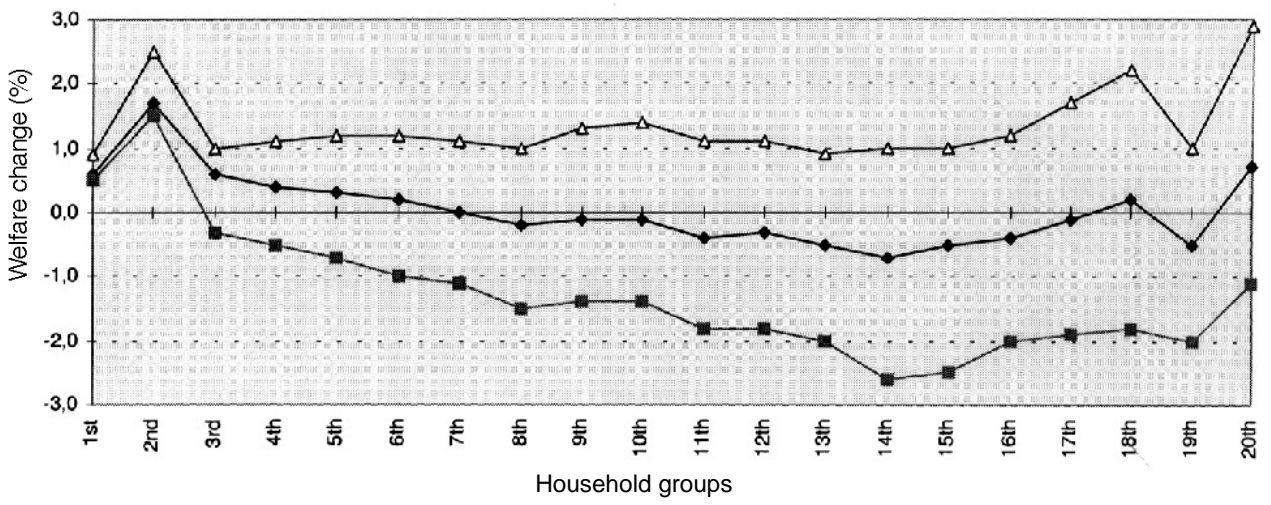

$\neg \bullet$ Flexible w ages $\rightarrow-$ Fixed w ages $\neg-$ Wage curve

Figure 4

The Impact on the Welfare of the Rural Groups

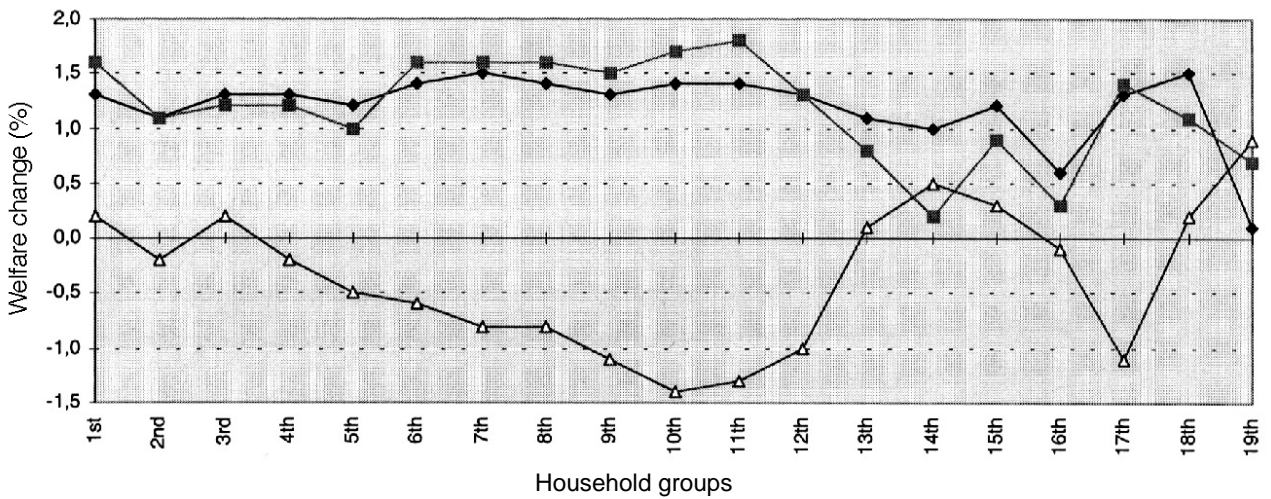

$\multimap$ Flexible w ages $\neg-$ Fixed w ages $\neg \curvearrowleft$ Wage curve

because of the large negative income effect, which is due to the value added contraction in the primary sector. In summary, although the preferential trading agreement with the EU is potentially Pareto superior, the welfare effects vary across the household groups, and according to the assumptions postulated for the labour market. 


\section{Figure 5}

The Impact on the Cost of Living Index of the Urban Groups

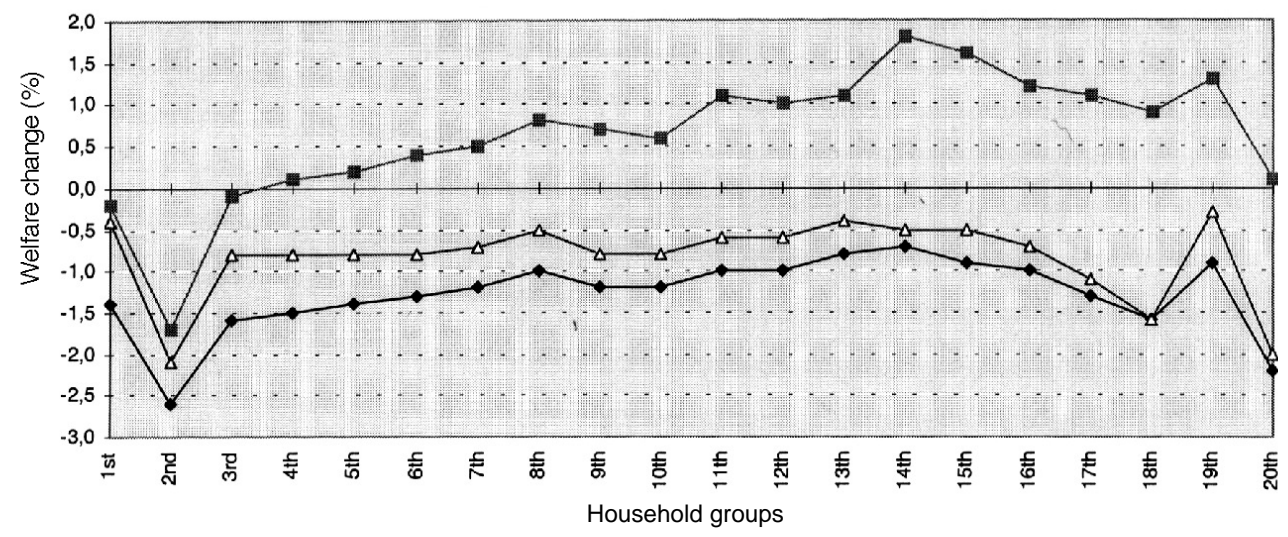

$\neg$ Flexible w ages $\rightarrow-$ Fixed w ages $\neg-$ Wage curve

Figure 6

The Impact on the Cost of Living Index of the Rural Groups

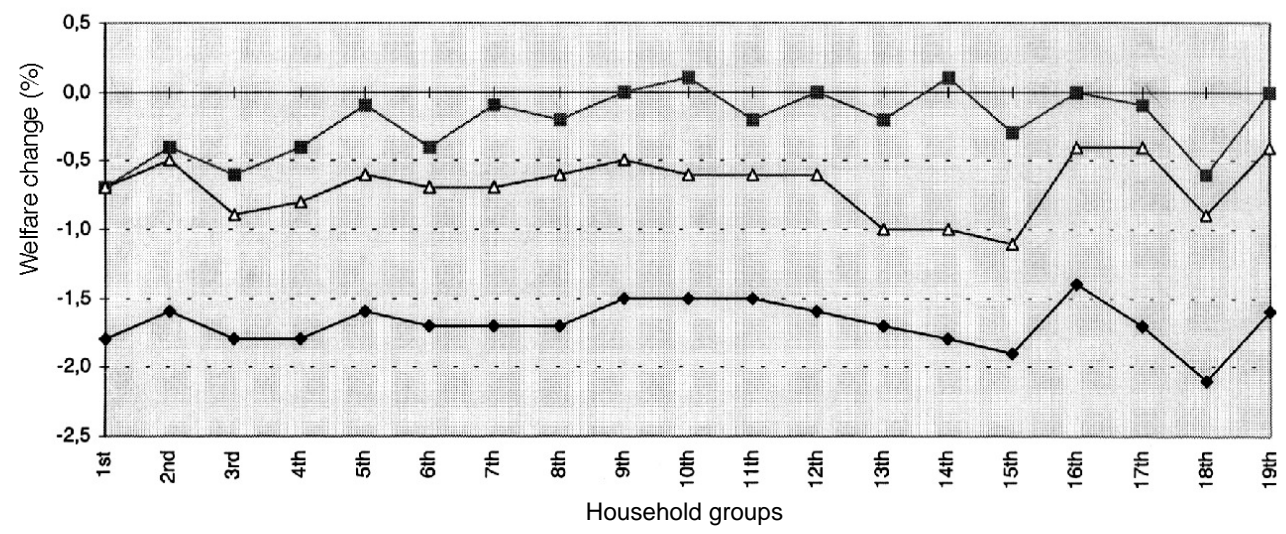

$\multimap$ Flexible w ages $\multimap-$ Fixed w ages $\neg\llcorner$ Wage curve

\section{E. The Impact on the Distribution of Income}

The impact on the size distribution of income, and the impact on the functional distribution of income, are shown in Tables 9 and 10. The first important finding is that, despite the relative large fall in tariffs, the impact on 
overall inequality is small. Thus, trade is not an important contributor of income inequality in Turkey. It decreases in the scenarios with fixed-flexible real wages, but increases in the wage curve scenario. The second striking result is that an important source of inequality improving (worsening) is a large positive (negative) impact on the inter-group inequality among urban and rural household groups. It decreases (rises) by 3.8-13.1\%(6.9-9.9\%) in the scenarios with fixed-flexible real wages (wage curve). These results are qualitatively shown in Figures 3 and 4 . In the scenarios with flexible and fixed real wages, the welfare of higher income urban households declines more in relative terms, whereas that of lower income rural households increases by a larger percentage, suggesting that inequality should decline within groups as well as between groups. The wage curve scenario yields the opposite outcome. Once again, these two different outcomes depend upon the performance of agricultural activities. In the scenarios with fixedflexible real wages (wage curve), agriculture expands (contracts), thus increasing (reducing) agricultural capital and labour incomes (see Table 10), which are the main components of private income in rural areas (see Table 3). The impact on inequality within groups is also in the same direction. It is important to emphasise the robustness of these results, which are independent of the value of the parameter $\theta$ used to estimate the generalised entropy indices. It must be stressed that measures with positive value of $\theta$ are particular sensitive to income differences at the top end of the income distribution, whilst measures with negative value of $\theta$ are more sensitive to very low income. This explains why the inequality within groups varies with $\theta$. In summary, the impact on income inequality depends highly upon the effect of the trade agreement on agriculture, as $53 \%$ of the Turkish population resides in rural areas, and most of the rural households are engaged in agricultural activities.

The results on inequality are less clear when the analysis on the income distribution effect is carried out by examining the impact on the functional distribution of income. In fact, the results indicate that in the scenarios with fixed and flexible real wages, the four ratios between (i) basic skilled and skilled labour incomes, (ii) non-skilled and skilled labour incomes, (iii) basic skilled labour and capital incomes, (iv) non-skilled labour and capital incomes, increase. This result is in line with the economic principle which 


\section{Table 9}

The Impact on the Size Distribution of Income

(percentage variation)

\begin{tabular}{|c|c|c|c|c|}
\hline$\theta$ & Inequality & Flexible wages & Fixed wages & Wage curve \\
\hline \multirow{4}{*}{-1} & Overall inequality & -1.1 & -2.2 & 0.6 \\
& Within urban areas & -1.1 & -2.2 & 0.2 \\
& Within rural areas & 0.0 & -0.1 & -0.8 \\
& Between rural-urban areas & -6.5 & -13.1 & 9.9 \\
& Overall inequality & -0.9 & -1.9 & 0.7 \\
& Within urban areas & -0.8 & -1.6 & 0.2 \\
& Within rural areas & -0.1 & -0.2 & -0.5 \\
& Between rural-urban areas & -6.4 & -13.0 & 9.7 \\
& Overall inequality & -0.8 & -1.8 & 1.2 \\
& Within urban areas & -0.4 & -1.2 & 0.5 \\
& Within rural areas & -0.2 & -0.5 & 0.0 \\
& Between rural urban areas & -3.8 & -7.7 & 6.9 \\
& Overall inequality & -0.6 & -2.1 & 2.4 \\
& Within urban areas & 0.0 & -0.9 & 1.3 \\
& Within rural areas & -0.5 & -1.2 & 0.7 \\
& Between rural-urban areas & -6.3 & -12.8 & 9.6 \\
\hline
\end{tabular}

states that the factors, which are intensively used in the most protected sectors, are hurt from trade liberalisation. In the flexible and fixed wages scenarios, both the labour incomes of production workers and agricultural workers rise relative to those of all other categories, because they are mostly employed in sectors where the reduction in tariffs is relatively smaller (see Table 10). The fall in the capital income, which is the result of the fall of the non-agricultural capital income, is due to the elimination of the rents originating from the VERs in textiles and wearing apparel. Conversely, in the wage curve scenario, basic skilled labour income increases while nonskilled labour income decreases with respect to both skilled labour income and capital income, due to a contraction of agricultural output. In addition, despite the rent loss as a result of the abrogation of the VERs, non-agricultural capital income rises because of the capital rent increase. In the wage curve scenario, therefore, the $\mathrm{CU}$ agreement causes a wage increase of the 
Table 10

The Impact on the Functional Distribution of Income

(percentage variation)

\begin{tabular}{|l|c|c|c|}
\hline & F lexible wages & Fixed wages & Wage curve \\
\hline A - Capital income & -1.2 & -0.2 & 0.1 \\
- Agricultural income & 0.6 & 3.1 & -3.4 \\
- Non-agricultural income & -1.6 & -1.0 & 0.9 \\
B - Labour income & -0.7 & 0.3 & -0.6 \\
B.1 - Skilled labour income & -1.3 & -1.4 & -0.3 \\
- Professional workers & -1.4 & -1.9 & -0.4 \\
- M anagerial workers & -1.3 & -0.2 & -0.1 \\
- Clerical workers & -1.3 & -1.3 & -0.1 \\
B.2 - Basic skilled labour income & -0.7 & 0.2 & 0.5 \\
- Sales workers & -0.8 & -3.0 & 0.3 \\
- Service workers & -0.8 & -1.6 & 0.0 \\
- Production workers & -0.7 & 1.3 & 0.7 \\
- Other workers & -0.9 & -0.4 & 0.4 \\
B.3 - Non-skilled labour income & 0.5 & 2.9 & -3.2 \\
- Agricultural workers & 0.5 & 2.9 & -3.2 \\
Basic skilled / Skilled labour income & 0.6 & 1.6 & 0.8 \\
Non-skilled / Skilled labour income & 1.9 & 4.4 & -2.9 \\
Basic skilled labour / Capital income & 0.5 & 0.4 & 0.4 \\
Non-skilled labour / Capital income & 1.7 & 3.2 & -3.3 \\
\hline
\end{tabular}

basic skilled workers relative to both the skilled workers, who are richer, and the non-skilled workers, who are poorer. Thus, one cannot drawn any conclusion regarding the impact on income distribution. By contrast, the analysis carried out with the generalised entropy indices clearly indicates that inequality would increase with trade. This suggests that theoretical and applied analysis of trade impact on the distribution of income, carried out only with models which define household groups according to their functional role and under the full employment assumption, might be ambiguous and misleading. 


\section{F. The I mpact on E mployment}

Table 11 reports the results concerning the impact of the $\mathrm{CU}$ agreement on Turkish employment, when real wages are either sticky or adjust to unemployment levels. The only exception is the treatment of the agricultural category. Since agriculture in Turkey is a family-based activity, it is assumed that trade policy affects only wages. The rigid real wages hypothesis leads to a decline of aggregate labour demand by $0.9 \%$ which implies that, as a consequence of the $\mathrm{CU}$ agreement, almost 100,000 jobs are lost. The job losses would mainly occur among professionals $(-2.5 \%)$, white collars $(-1.9 \%$, sale workers $(-3.6 \%)$ and service workers $(-2.2 \%)$, while new jobs for production workers $(0.7 \%)$ would be created due to the growth of textiles, wearing apparel leather and fur products. Conversely, the wage curve hypothesis leads to an expansion of the aggregate labour demand by $0.4 \%$ which implies that, as a consequence of the trade policy, almost 60,000 new jobs are created. It is interesting to note that $63 \%$ of new jobs are for basic skilled production workers, who are demanded by the growing manufacturing industries.

Table 11

The Impact on Employment

\begin{tabular}{|l|c|c|c|c|}
\hline & \multicolumn{2}{|c|}{ Fixed wages } & \multicolumn{2}{c|}{ Wage curve } \\
\hline & $\begin{array}{c}\text { Relative change } \\
(\%)\end{array}$ & $\begin{array}{c}\text { Change in } \\
\text { employment }\end{array}$ & $\begin{array}{c}\text { Relative change } \\
(\%)\end{array}$ & $\begin{array}{c}\text { Change in } \\
\text { employment }\end{array}$ \\
\hline Labour Input & -0.9 & $-101,435$ & 0.4 & 60,353 \\
- Professional workers & -2.5 & $-26,151$ & 0.2 & 2,268 \\
- M anagerial workers & -0.8 & $-2,472$ & 0.4 & 1,185 \\
- Clerical workers & -1.9 & $-16,670$ & 0.4 & 3,141 \\
- Sales workers & -3.6 & $-53,551$ & 0.6 & 8,929 \\
- Service workers & -2.2 & $-32,734$ & 0.4 & 6,114 \\
- Agricultural workers & 0.0 & 0 & 0.0 & 0 \\
- Production workers & 0.7 & 31,389 & 0.8 & 37,914 \\
- Other workers & -1.0 & $-1,246$ & 0.6 & 803 \\
\hline
\end{tabular}


As discussed in section [4.1], the effects on the labour market depend upon the impact on the nominal wages of all labour categories and on the producer price index. The fixed real wage hypothesis implies that the nominal wages and the producer price index ought to change by the same proportion. As the labour demand expands due to the $\mathrm{CU}$ agreement, the nominal wages rise. However, in equilibrium, the producer price index ought to rise by the same proportion. Given the world prices of exports, the producer price index can rise if, and only if, the domestic prices increase. The latter result has a negative effect on domestic demand, which causes output contraction and a backward shift of the labour demand schedules (see Figure 2). At sectoral level, however, manufacturing activities expand (see Table 6). As a result, production workers are the only category where new jobs are created. In contrast, in the wage curve hypothesis, the rise in nominal wages are not compensated fully by a rise in producer prices. Given the negative relationship between real wages and unemployment, a rise in real wages can occur if, and only if, new jobs are created (see Figure 2). In particular, since both industry and service grow (see Table 6), all labour categories record a positive effect on employment.

\section{G. The I mpact on the Indirect Tax Rates}

It is important to stress that, given the ex-ante large tariff rates, these results are obtained if the indirect tax rates used to perform a revenue-neutral tariff reform are uniformly increased by $46.7 \%$ in the case of flexible real wages, by $42.6 \%$ in the scenario with fixed real wages, and by $41.7 \%$ in the wage curve scenario. In other words, the standard VAT rate should rise from $15 \%$ (the prevailing rate in Turkey in 1994) to $21.3 \% 22 \%$ which is higher than the standard VAT rate applied in most of the European member states. It is interesting to note that $\mathrm{H}$ arrison, et al. [1996, 1997] compute an increase in the VAT rate by only $24.6 \%$ in the scenario which is comparable to the simulation run in this study. It is not clear if this is simply due to the different definition of the tax base. I am confident about the results reported in this study because the statistics on Turkish Treasury accruals and receipts by type of revenues indicate that, during the first half of ' 90 s, the custom duty and funds represented almost $40 \%$ of taxes on goods and ser- 
vices including the VAT on imports (SIS [1998]). Once the obligations of the CU agreement will be fulfilled by the year 2001 , I estimate that the tariff revenues will be one quarter the actual value in real terms, which implies that Turkey will lose tariff revenues equal to $1.8-1.9 \%$ of GDP, rather than $1.4 \%$ as estimated by Harrison, et al. [1996, 1997]. ${ }^{27}$

\section{Conclusions}

The aim of this study is to analyse the impact of the CU agreement between Turkey and the EU on the welfare and the size distribution of income among urban and rural Turkish households; and on Turkey's employment, sectoral output, GDP and trade flows. In order to examine the impact of the CU upon employment, three alternative hypotheses for the Turkish labour market have been postulated: (i) full employment and flexible real wages; (ii) unemployment and fixed real wages; (iii) unemployment and flexible real wages, which adjust to unemployment levels (i.e. wage curve hypothesis). These three scenarios can be also used to answer the following question: how robust is the model to alternative functional forms for the labour market?

The model seems quite robust regarding the impact on production, trade and tax revenues. In fact, all scenarios indicate that manufacturing production and trade, in particular in textiles, wearing apparel, leather and fur products, expand despite the loss of protection in manufacturing; and that the standard VAT rate on all goods and services should increase to $21-22 \%$ for the trade policy to be revenue neutral. Whereas the results on welfare, income distribution and employment depend largely upon the type of assumption postulated, as they are strongly affected by the impact on agriculture. In the wage curve scenario, urban households are better off, rural households are worse off and income inequality increases; whereas in the

27. To evaluate the robustness of the above results, sensitivity analysis on the elasticity values and functional forms has been carried out. The results clearly show that the direction of the variable changes is robust, however their precise size depends upon the value of the elasticities and the type of functional forms adopted. Some variation in the individual sectoral impact also exists. 
scenarios with fixed or flexible real wages, urban household are worse off, rural households are better off and income inequality decreases. In the wage curve scenario, an important source of income inequality is the interincome inequality between urban and rural areas, which rises by $6.9-9.9 \%$ due to an output fall in agriculture, a sector still protected and the principal income source of rural households. Regarding the impact on employment, the preferential trading agreement with the EU leads to a loss in jobs if real wages are rigid, or the creation of new jobs if the labour market is described by the wage curve hypothesis. Nevertheless, due to the expansion of textiles, wearing apparel, leather and fur products, basic skilled production workers jobs are created under both assumptions.

This analysis leads directly to an other important result, which is related to the issue of international trade and income inequality. D espite the large fall in tariffs, the impact on overall inequality is small, suggesting that trade is not the key factor in explaining large changes in the distribution of income.

It should be stressed that, although the hypotheses postulated for the labour market are not based upon an econometric testing procedure, the results of this study, especially those on indirect taxation, welfare, income distribution and employment, can be of some interest to policy-makers. Certainly, complementary econometric studies, which can characterise the features of the labour market in Turkey in more detail, are essential for the adoption of appropriate economic policy measures. However, the statistics of the State Planning Organisation of Turkey for the two-year period 19961997 indicate that agriculture stagnated, whilst industry and services expanded by a large growth rate (on average 8.4\%per year), which is double the average growth rate recorded during the period 1990-1995. In particular, the production index in textiles, wearing apparel and leather have recorded a remarkable growth with respect to the previous trends. Regarding employment, industry and services have created almost 1,050,000 new jobs during the period October 1995 - April 1998 (30 months). An increase in labour demand of this size has been recorded during the longer period April 1991 - October 1995 (54 months). This implies that the predictions of the wage curve model seem to be more appropriate to explain the recent stylised facts of the T urkish economy. 


\section{References}

Bartel, A. P. and Lichtenberg, F. R. [ 1987], "The Comparative Advantage of Educated Workers in Implementing New Technology," Review of E co nomics and Statistics 69; pp. 1-11.

Berndt, E. R., C. J. M orrison, and Rosenblum, L. S. [1992], "High-Tech Capital Formation and Labour Composition in U.S. M anufacturing Industries: An Explanatory Analysis," NBER, N o. 4010.

Blanchflower, D. G. and Oswald, A. J. [1994], The Wage Curve, Cambridge, The MIT Press.

Boadway, R. W. [1974], "The Welfare Foundations of Cost-benefit Analysis," Economic Journal 84; pp. 926-939.

B ourguignon, F. [1979], "D ecomposable Income Inequality M easures," Econometrica 47; pp. 901-920.

Bulutay, T. [1995], Employment, Unemployment and Wages in Turkey, Ankara, SIS.

Celasun, M. [1994], "T rade and Industrialization in Turkey: Initial Conditions, Policy and Performance in the 1980s," in Helleiner, G. K. (ed.), Trade Policy and Industrialization in Turbulent Times, London, Routledge.

Cowell, F. A. [1980], "On the Structure of Additive Inequality M easures," Review of Economic Studies 47; pp. 523-531.

Cowell, F. A. [1984], "The Structure of American Income Inequality," Review of Income and Wealth 30; pp. 351-375.

Cowell, F. A. [1995], Measuring Inequality, London, Princeton Hall/ Harvester Wheatsheaf.

Cowell, F. A. and Kuga, K. [1981a], "Inequality Measurement - an Axiomatic Approach," European Economic Review 15; pp 287-305.

Cowell, F. A. and Kuga, K. [1981b], "Additive and Entropy Concept: An Axiomatic Approach to Inequality M easurement," Journal of E conomic Theory 25; pp 131-143.

Danziger, S. and Taussig, M. K. [1979], "The Income Unit and the Anatomy of Income Distribution," Review of Income and Wealth 25; pp. 365-375.

De Santis, R. A. [1998], "The Impact of a Customs Union with the EU on Turkey's Internal Migration under the two Alternative Harris-Todaro 
and 'Wage Curve' Settings," Kiel Institute of World Economics, Kiel Working Papers, No. 867.

De Santis, R. A. and Ozhan, H. G. [1995], "A Social Accounting M atrix for Turkey 1990," INFORUM Working Papers, Department of E conomics of University of M ar yland at College Park, No. 1.

De Santis, R. A. and Ozhan, H. G. [1997], "Social Accounting Matrix for Turkey 1990," E conomic System Research 9; pp. 281-285.

EC [1996], The Agricultural Situation in the European Union: 1995 Report, Brussels.

GATT [1994], Trade Policy Review: The Republic of Turkey 1994, Geneva.

Glewwe, P. [1991], "Household Equivalence Scales and the M easurement of Inequality. Transfers from the Poor to the Rich could Decrease Inequality," Journal of Public E conomics 44; pp. 211-216.

Griliches, Z. [1969], "Capital-skill Complementarity," Review of E conomics and Statistics 51; pp. 465-468.

Hoddinott, J. [1996], "Wages and Unemployment in an Urban African Labour M arket," E conomic Journal 106; pp. 1610-1626.

Harrison, G. W., Rutherford, T. F. and Tarr, D. G. [1992], "Piecemeal Trade

Reform in Partially Liberalised Economies: an Evaluation for Turkey," World Bank Working Papers, Country E conomics D epartment, No. 951. Harrison, G. W., Rutherford, T. F. and Tarr, D. G. [1996], "E conomic Implications for Turkey of a Customs Union with the European Union," World Bank Policy Research Working Papers, N o. 1599.

Harrison, G. W., Rutherford, T. F. and Tarr, D. G. [1997], "Economic Implications for Turkey of a Customs Union with the European Union," European Economic Review 41; pp. 861-870.

Kirmanoglu, H. and Yazgan, M. E. [1998], "Distributional Dynamics in the

Turkish Manufacturing Industry," Presented at the 2nd METU International Conference on E conomics, Ankara.

Mansur, A. H. and Whalley, J. [1984], "N umerical Specification of Applied General Equilibrium Models: Estimation, Calibration and Data," in Scarf, H. E. and Shoven, J. B. (eds.), Applied General Equilibrium Analysis, Cambridge, Cambridge University Press.

Mercenier, J. and Yeldan A. E. [1997], "On Turkey's Trade Policy: Is a Customs Union with Europe Enough?," European E conomic Review 41; pp. 
871-880.

OECD [1992], OECD E conomic survey. Turkey 1991/ 1992, OECD, Paris.

OECD [1994], OECD E conomic survey. Turkey 1993/ 1994, OECD, Paris.

Onaran, Ö [1999], "The Wage Setting M echanism in Private M anufacturing Industries and its Effect on the Labour Market in Turkey," Istanbul

Technical University Discussion Papers, No. 99/ 5.

Shorrocks, A. F. [1980], "The Class of Additively Decomposable Income Inequality M easures," E conometrica 48; pp. 613-625.

State Institute of Statistics Prime M inistry Republic of Turkey - SIS [1994],

The Input-Output Structure of the Turkish E conomy 1990, Ankara.

SIS [1998], Statistical Yearbook of Turkey 1997, Ankara.

State Planning Organisation of Turkey - SPO, Main Economic Indicators, Ankara, various issues.

Togan, S. [1994], Foreign Trade Regime and Trade Liberalisation in Turkey During the 1980s, Aldershot, Avebury.

Togan, S. [1997], "Opening up the Turkish Economy in the Context of the Customs Union with the EU," Journal of E conomic Integration 12; pp. 157-179.

Wood, A. [1994], North- South Trade, Employment and Inequality. Changing Fortunes in a Skill-Driven World, Oxford, Clarendon Press. 